\title{
Microvegetation on the top of Mt. Roraima, Venezuela
}

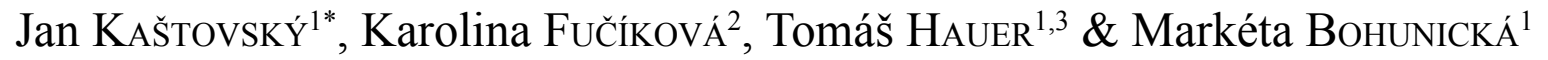 \\ ${ }^{1}$ Faculty of Science, University of South Bohemia, Branišovská 31, České Budějovice 37005, Czech Republic; \\ *e-mail: hanys@prf.jcu.cz \\ ${ }^{2}$ University of Connecticut, Department of Ecology and Evolutionary Biology, 75 North Eagleville Road, Storrs, \\ CT 06269-3043, U.S.A. \\ ${ }^{3}$ Institute of Botany of the Academy of Sciences, Czech Republic, Dukelská 135, Třebon̆ 37982, Czech Republic.
}

\begin{abstract}
Venezuelan Table Mountains (tepuis) are among world's most unique ecological systems and have been shown to have high incidence of endemics. The top of Roraima, the highest Venezuelan tepui, represents an isolated enclave of species without any contact with the surrounding landscape. Daily precipitation enables algae and cyanobacteria to cover the otherwise bare substrate surfaces on the summit in form of a black biofilm. In the present study, 139 samples collected over 4 years from various biotopes (vertical and horizontal moist rock walls, small rock pools, peat bogs, and small streams and waterfalls) were collected and examined for algal diversity and species composition. A very diverse algal flora was recognized in the habitats of the top of Mt. Roraima; 96 Bacillariophyceae, 44 Cyanobacteria including two species new to science, 37 Desmidiales, 5 Zygnematales, 6 Chlorophyta, 1 Klebsormidiales, 1 Rhodophyta, 1 Dinophyta, and 1 Euglenophyta were identified. Crucial part of the total biomass consisted of Cyanobacteria; other significantly represented groups were Zygnematales and Desmidiales. Investigated biotope types were demonstrated to have different composition of algal communities.
\end{abstract}

Key words: algae, Cyanobacteria, endemism, new species, Roraima, Table Mountain, tepuis

\section{Introduction}

Terrestrial biotopes such as bare rock surfaces are often exposed to unstable water regimes, high insolation and great temperature fluctuations. Therefore the occurrence and composition of living organisms of these biotopes depend highly on environmental conditions, in particular on chemical and physical conditions.

Algae and cyanobacteria are common inhabitants of the terrestrial habitats, often forming contiguous films that cover the rock surface. These biofilms are usually formed by mixed communities of unique composition, which is determined by different requirements of each of the living form. Terrestrial cyanobacteria are able to desiccate and are thus adapted to the unstable water regime, but for their metabolic activity and photosynthesis they require water in liquid state, whereas eukaryotic algae are able to utilize water vapour (LANGE et al. 1988; BÜDEL \& LANGE 1991; JEFFRIES et al. 1993a, b).

Because of the extreme character of habitats on rock surfaces, the organisms that are able to survive such conditions are of substantial interest to biologists. In the first half of the $20^{\text {th }}$ century, three comprehensive studies on rockinhabiting microorganisms were conducted: Diels (1914) investigated dolomites, NovÁČEK (1934) serpentinites, and JAAG (1945) limestones and silicates. However, only fairly recently have such mountain terrestrial habitats received great attention of phycologists (BÜDEL et al. 1994 in south America; Watanabe \& KomÁreK 1994 in Nepal; Casamatta et al. 2006 in North America; Neustupa \& ŠKaloud 2008 in Southeast Asia; Hauer \& Pažoutová 2009 in Europe).

\section{Mt. Roraima}

Venezuelan Table Mountains are a result of more than 1 billion-year-long weathering of the thick quarzite and sandstone sedimentary cover of the Guyana shield (STEYERMARK et al.1995). The mineral content of the parent rocks is low and the soils above them are poor in nutrients $(\mathrm{P}, \mathrm{Ca}, \mathrm{N})$ but rich in aluminium compounds that represent yet another stress factor for the region's vegetation (FÖlSTER \& HUBER 1984; FölSTER 1986).

Venezuela's highest tepui, Mt. Roraima, is situated on the border of Venezuela, Guyana, and 
Brazil (Fig.1). The mountain is $2806 \mathrm{~m}$ tall and the upper plateau (meseta; ca $40 \mathrm{~km}^{2}$ ) is elevated 800-1100 $\mathrm{m}$ above the surrounding savanna. This condition limits any contact of the species on the meseta with the surrounding landscape, resulting in high endemism (fungi: Strobel et al. 1999, 2001; mosses: BuCK \& CRUM 1993; higher plants: Steymark 1987; Steyermark et al.1995; Michelangeli 2000; insects: Spangler 1985 a,b; Spangler \& Faitoute 1991 and vertebrates: Perezzapata 1992; Campbell \& Clarke 1998, Myers \& Donnelly 2001). Moreover, the world's longest cave system found in quartz rock Cueva Ojos de Cristal (Crystal Eyes Cave) - was discovered and reported by AuDy (2008), adding to the unique features of the locality.

The average annual temperature is approximately $10-15^{\circ} \mathrm{C}$, but the temperature of the rock surface fluctuates rapidly, as the weather continually changes. For instance, $7{ }^{\circ} \mathrm{C}$ was the measured minimum (6 AM) and $42{ }^{\circ} \mathrm{C}$ the maximum measured at 10:30 AM on the same day $\left(27^{\text {th }}\right.$ Jan. 2000). The nutrient cycles on tepuis are thought to be affected considerably by levels of sunlight due to photosynthetic activity of the flora on the surface (BRICENO et al. 1990). The characteristic water regime of the tepuis formed by daily ample precipitations in combination with air humidity and soil moisture is a result of a unique geomorphology. This regime rich in frequent fogs and rains allow for the creation of various microhabitats suitable for the biofilms formation.

\section{Aims of the study}

The primary goal of the present work was to provide a basic floristic survey of the algal and cyanobacterial vegetation living on the top of Roraima Tepui. Since this locality provides a variety of habitats differing considerably in physical conditions, a comparison of these different habitat types was also carried out with respect to algal and cyanobacterial flora. In addition, the results of the floristic/taxonomic work were used to determine whether the algal and cyanobacterial flora reflects the levels of endemism found in animals, fungi, and higher plants.

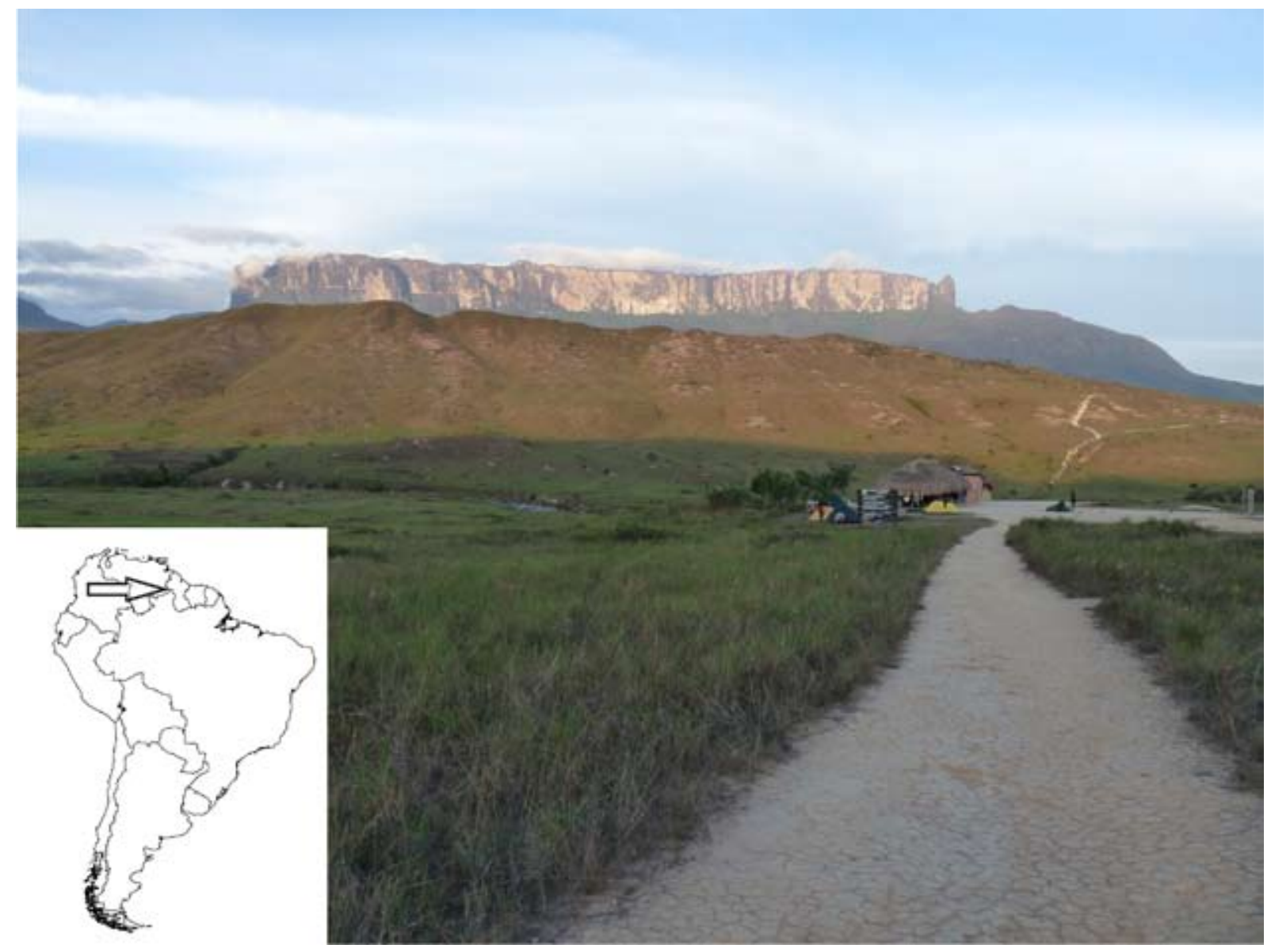

Fig. 1. Mt. Roraima 


\section{Materials and methods}

An expedition from the Faculty of Science, University of South Bohemia sampled different types of habitats on the upper plateau of Mt. Roraima in January 2000, 2004, 2006, and 2009. The sampling included vertical rock walls (17 samples), horizontal rocks (23), small rock pools (lacking an organic layer on the bottom - 14), peat bogs (23), streams (26), waterfalls (17), and rock overhangs (19). A total of 31 samples were collected in 2000, 6 in 2004, 36 in 2006, and 66 in 2009. Samples were obtained by careful scraping off the substrata with a knife and were subsequently fixed in $1.5 \%$ formaldehyde solution and transported (samples from 2006 and 2009 were preserved by drying only).

Preserved samples were directly analyzed using a light microscope Olympus BX 51 with high resolution Nomarski DIC optics equipped with digital camera Olympus DP 71 and software DP Controller (Olympus Inc.). From samples containing significant amount of diatom frustules, permanent diatom slides were prepared following protocol by Houk (2003), using hydrogen peroxide for digestion, and Pleurax artificial resin (FOTT 1954) as a mounting medium.

For the estimation of relative density of species we used the phycological variation of the geobotanical Braun-Blanquet scale (KAŠTOvsKÝ et al. 2008). The data were analyzed by CCA and DCA analysis using CANOCO for Windows (TER BRAAK \& ŠMILAUER 2002).

\section{Results and discussion}

All species found on Mt. Roraima and their relative abundances in particular biotopes are listed in Supplementary Table 1. (electronic version only at http://fottea.czechphycology.cz)

\section{Cyanobacteria}

With respect to biomass, the most important group of algae found on the top of Roraima were Cyanobacteria, represented by 44 species. The most abundant genera were Stigonema (especially S. ocellatum (Dillwyn) ThURET ex Bornet et Flahault and $S$. hormoides (KÜtZING) Bornet et Flahault, Figs. 2/13 and 2/9) and Gloeocapsa (especially G. sanguinea (C. AGARDH) KüTZING, Figs. 2/1 and 2). In addition to species identifiable using available literature (GEITLER 1932; KOMÁREK \& ANAGNOSTIDIS 1998, 2005), we found numerous cyanobacteria of unclear taxonomic affiliation. These forms are listed and characterized below. Schizothrix cf. telephoroides (Fig 2/10), found in all types of habitats, abundant especially on vertical rocks and peat bogs. Cells $2-3 \mu \mathrm{m}$ wide,
1.5-2 times longer than wide. Trichomes green, 1-2 per sheath. Sheath red to red-brown, closed at tip, distinctly lamellated, (15) 17-20 (25) $\mu \mathrm{m}$ wide. This morphology does not entirely fit any currently recognized species. S. telephoroides (Montagne) Gomont is the closest match but has considerably wider cells $(4-9 \mu \mathrm{m})$. GoLUBIĆ (1967b) reported this species from wet rock walls in Venezuela, and indicated its cell width similar to our findings (3.2-3.5 (4) $\mu \mathrm{m})$.

Porphyrosiphon cf. notarisii (Fig.2/11), found rarely but represented in all habitats except flowing water. Cells isodiametric, $5 \mu \mathrm{m}$ in size, distinctly constricted at cross walls, granulated, yellow-brown. Sheath lamellated, yellow to brown, open at tip, considerably longer than trichome. Generally one trichome per sheath, two in rare cases of branching. Filament including sheath 40-50 $\mu \mathrm{m}$ wide. Such sheath width and character is not common in this genus. $P$. notarisii (Meneghini) Kützing ex Gomont is Porphyrosiphon with the widest sheath (up to 30 $\mu \mathrm{m})$ but it has cells of more than double the size observed here.

More subtle differences(small discrepancies in size, colour, somewhat atypical habitat) from known species were found in a number of cyanobacteria from Roraima. For example, Xenotholos cf. kernerii (Figs.2/3 and 7; epiphytic on Stigonema spp.) had brown to brown-yellow cells, whereas the original description of the species reports green cells. Homoeothrix cf. juliana (Figs. 2/6 and 8), an inhabitant of rocks in waterfalls and streams, had very dark-brown sheaths as opposed to the originally described yellow sheaths in $H$. juliana (THURET ex BORNET et Flahault) Kirchner. Moreover, the original is supposedly fairly strictly tied to limestone streams. Hapalosiphon cf. luteolus (Figs. $2 / 14$ and 15) was of identical dimensions and morphology to the type species (especially the conspicuous and frequent secondary branching of side branches), but unlike the yellow-sheathed original, the Roraima inhabitant had colourless sheaths. Merismopedia cf. elegans (Fig. 2/4) was found in the epipsammon in a calmly flowing cave stream, but $M$. elegans A. BRAUN ex KÜTZING is a species inhabiting the littoral of eutrophic or slightly acidic standing waters. Character of cells of a taxon designed as Gloeothece sp. 1 (Fig. 2/5) notably resembled the genus Rhabdoderma SCHMIDLE et LAUTERBORN, but Rhabdoderma was never observed to form sheaths around individual 
Table 1. Differences of newly described and other ecologically or morphologically similar Enthophysalis species.

\begin{tabular}{|c|c|c|c|c|c|}
\hline & $\begin{array}{l}\text { colony } \\
\text { shape }\end{array}$ & $\begin{array}{c}\text { colony } \\
\text { size } \\
(\mu \mathrm{m})\end{array}$ & $\begin{array}{l}\text { cell size } \\
\quad(\mu \mathrm{m})\end{array}$ & sheaths & ecology \\
\hline Entophysalis granulosa KüTZING & $\begin{array}{l}\text { macrosco- } \\
\text { pic, shrub- } \\
\text { like }\end{array}$ & $<1000$ & $2-5$ & $\begin{array}{l}\text { brown, yel- } \\
\text { low, colour- } \\
\text { less }\end{array}$ & $\begin{array}{l}\text { marine (spla- } \\
\text { sh zone) }\end{array}$ \\
\hline Entophysalis violacea GARDNER & $\begin{array}{l}\text { microsco- } \\
\text { pic, cushi- } \\
\text { on-like }\end{array}$ & $>80$ & $1.5-2.5$ & violet & rocks \\
\hline Entophysalis arboriformis sp. nov. & $\begin{array}{l}\text { macrosco- } \\
\text { pic, shrub- } \\
\text { like }\end{array}$ & $\sim 1000$ & $4-6$ & $\begin{array}{l}\text { red to colour- } \\
\text { less }\end{array}$ & $\begin{array}{l}\text { aerophy- } \\
\text { tic, wet } \\
\text { rocks,sand- } \\
\text { stone }\end{array}$ \\
\hline
\end{tabular}

Table 2.Differences between $A$. torulosa and $A$. roraimae.

\begin{tabular}{|c|c|c|c|c|c|c|}
\hline & ecology & color & $\begin{array}{l}\text { hormogo- } \\
\text { nia }\end{array}$ & $\begin{array}{l}\text { filament } \\
\text { width } \\
(\mu \mathrm{m})\end{array}$ & $\begin{array}{l}\text { cells } \\
\text { width } \\
(\mu \mathrm{m})\end{array}$ & $\begin{array}{c}\text { cells } \\
\text { lenght } \\
(\mu \mathrm{m})\end{array}$ \\
\hline Albrightia torulosa Copeland & $\begin{array}{l}\text { epiphyte } \\
\text { on bigger } \\
\text { cyanobacte- } \\
\text { ria, thermal } \\
\text { springs }\end{array}$ & $\begin{array}{c}\text { blue-gre- } \\
\text { en }\end{array}$ & $\begin{array}{c}\text { mostly } 2 \\
\text { cells }\end{array}$ & $5-8.5$ & $3.2-4$ & $3.3-9.0$ \\
\hline Albrightia roraimae sp. nov. & $\begin{array}{l}\text { benthos from } \\
\text { rock pool, } \\
\text { wet rock } \\
\text { epilith }\end{array}$ & brown & $\begin{array}{c}\text { mostly } 5 \\
\text { cells }\end{array}$ & $14-16.5$ & (4) $5.3-8$ & (4) $15-19$ \\
\hline
\end{tabular}

cells in a colony.

Two cyanobacterial taxa occurring on Mt. Roraima were morphologically significantly different from any currently recognized species. We here propose these as new species, even if solely based on a botanical-morphological approach.

\section{Entophysalis arboriformis sp. nov. (Fig. 3)}

Diagnosis: Coloniae micro- vel macroscopicae, gelatinosae, amorphae, despues plus minusve erectae, irregulares, ramosae lobataeque, divaricatae, ad $1000 \mu \mathrm{m}$ longae, rubrae, cum cellulis solitariis vel irregulariter aggregatis in subcoloniis parvis cum involucra mucilaginosa circumdatis, praecipue in partes marginalibus coloniae agglomeratis. Cellulae plus minusve ovales ad irregulares, olivaceo virides, intendum contentu granuloso, 4-6 $\mu \mathrm{m}$ in diametro. Involucra interna ad 11 (13) $\mu m$ lata, concentrice lamellosa, granulosa, diffluentes, intense rubra. Involucra externa lata, sine colore, mucilaginosa, cum matrice externa confluentes. Nanocytae sporaeque carentes.
Ecologia: Aerophytice ad rupes humidas areanrias inter species cyanoprocaryoticis.

Locus classicus: Mons Roraima Dictus, Venezuela.

Holotypus: specimina conservata in herbarium BRNM (Museum Moravicum Brno, Res Publica Bohemia) deposita (BRNM HY 2259).

Icona typica: figura nostra 3

Micro-, later macroscopic shrub-like gelatinous colonies composed of ensheated solitary cells joined into smaller subcolonies concentrated on periphery of the colony. Cells more or less oval or irregular, olive green, sometimes granulated, 4-6 $\mu \mathrm{m}$ in diameter. Inner mucilaginous envelopes up to $11 \mu \mathrm{m}$ wide, concentrically lamellated, granulated, diffluent, red. Outer envelopes large, diffluent, colorless, forming inner mass of the colony. Nanocyte production and resting cells not observed.

Ecology: Aerophytic cyanobacterium, growing 


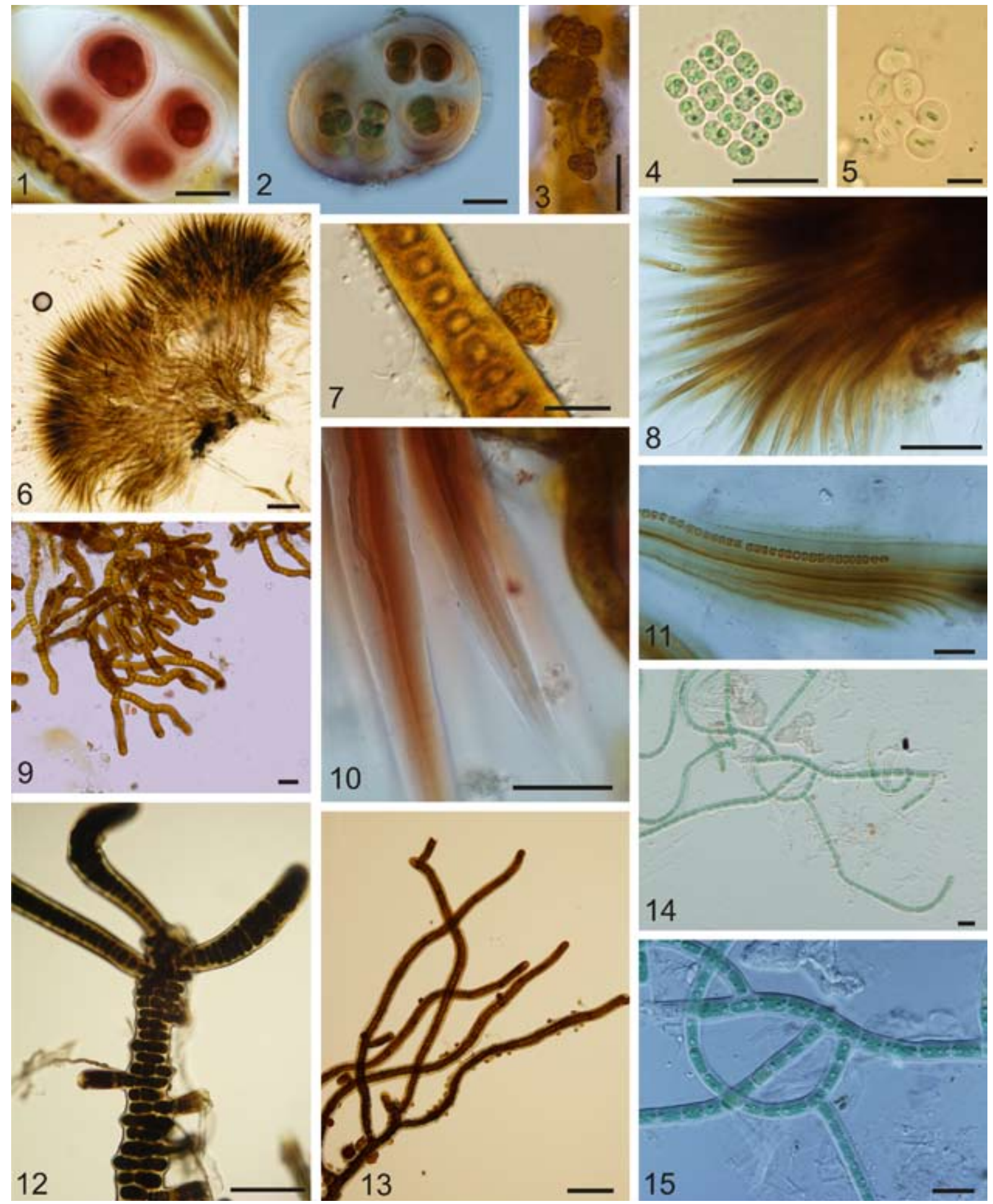

Fig. 2. Cyanobacteria: $(1,2)$ Gloeocapsa sanguinea; $(3,7)$ Xenotholos cf. kernerii; (4) Merismopedia cf. elegans; (5) Gloeothece sp. 1; (6, 8) Homoeothrix cf. Juliana; (9) Stigonema hormoides; (10) Schizothrix cf. telephoroides; (11) Porphyrosiphon cf. notarisii; (12) Stigonema informe; (13) Stigonema ocellatum; (14, 15) Hapalosiphon cf. luteolus. Scale bars $100 \mu \mathrm{m}(6,8$, 12,13); $20 \mu \mathrm{m}(1-5,7,9-11,14)$. 
on wet walls among other, especially filamentous cyanobacteria.

Locus classicus: Mount Roraima, Venezuela.

Samples: rare, found in five samples, all in relative abundance up to 3 .

Holotype: Preserved material deposited at the herbarium of the Moravian Museum Brno (BRNM HY 2259).

Icona typica: our Figure 3

Differences from other ecologically or morphologically similar Entophysalis species are summarized in Table 1.

\section{Albrightia roraimae sp. nov. (Fig.4)}

Diagnosis: Filamenta intertexta, 14-16.5 4 m lata, recte ramosa, ramuli ad angulum latum patentes. Trichomata ramique uniseriatae, cylindricae, moniliformes, ad dissepimenta clare constrictae, ad apices non attenuatae. Cellulae fuscae, barriliformes ad ovales, interdum cum connectivis cytoplasmaticis connectae,

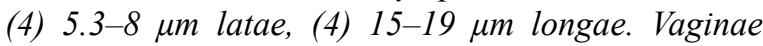
firmae, latae, homogeneae, luteo-fuscae. Heterocytae akinetesque carentes. Reproductio cum hormogoniis 5-7-cellularis, 40-55 $\mathrm{mm}$ longis (cum cellulis 18-21 $\mu \mathrm{m}$ latis, 6.5-8 $\mu \mathrm{m}$ longis), de ramulis curtis vel lateraliter de filamentis principalibus crescentes.

Ecologia: benthice, periphytice, inter cyanobacteria filamentosa in fossis petrosis ad saxa humida.

Locus classicus: Mons Roraima dictus, Venezuela.

Holotypus: specimima conservata in herbarium

BRNM (Museum Moravicum Brno, Res Publica

Bohemia) deposita (BRNM HY 2260).

Icona typica: figura nostra 4

Trichomes uniseriate, cylindrical, composed of moniliform row of cells, with deep constrictions at cross walls. Branches formed at wide angles and of the same morphology and size as main filaments. Cells brown, barrel-shaped to oval, sometimes with visible cytoplasmatic connections. Sheaths thick, firm, homogenous and yellow-brownish. Heterocytes and akinetes not observed.

Width of filaments $14-6.5 \mu \mathrm{m}$, cells (4) 5.3-8 wide, (4) 15-19 $\mu \mathrm{m}$ long. Reproduction by few-celled (5-7 cells) hormocytes (ensheated hormogonia, similar to hormocytes of more known genus Westiella), 40-55 $\mu \mathrm{m}$ long. Unlike Westiella hormocytes are not at the end of long lateral branch but on very short branch or directly on the main filament. Width of hormocytes cells 18-21 $\mu \mathrm{m}$, length $6.5-8 \mu \mathrm{m}$.

This species' morphology corresponds with the monotypic genus Albrightia COPELAND 1936, but not with the only existing species $A$. torulosa Copeland (Copeland 1936) - see Table 2.
Ecology: Benthic and periphytic among other filamentous cyanobacteria, in rock pools and on wet rocks.

Locus classicus: Mount Roraima, Venezuela.

Samples: rare, in rock pools (one sample) and on horizontal rocks (one sample), in both in relative abundance 2 .

Holotype: Preserved material deposited at the herbarium of the Moravian Museum Brno (BRNM HY 2260).

Icona typica: our figure 4

Differences from other described Albrightia species are summarized in Table 2.

Apart from these two taxa, we found other morphologically unusual cyanobacteria (cf. Cyanokybus, cf. Gomphosphaeria, cf. Romeria) that we were not confident to assign even to a genus. These forms were extremely rare (one to few individuals found) and therefore there was not enough material for their thorough examination.

\section{Conjugatophyceae}

The second-most important group was the Conjugatophyceae, represented by 42 species (37 Desmidiales, 5 Zygnematales); however their biomass was relatively low in all sampled habitats, with the exception of Zygogonium sp., the densities of which were fairly high in peat bogs and on vertical rocks. A complete overview of desmids found on Roraima is presented in Supplementary Table 1 and in Supplementary Figures 1 and 2 (electronic version only at fottea.czechphycology. cz). The most common and/or taxonomically important taxa are discussed below.

Some species were observed frequently (Actinotaenium cucurbita (BRÉBISSON ex RALFs) TeILING - Suppl. Fig. 1/4, and all varieties of Micrasterias arcuata BAILEY - Suppl. Fig. 2/1-4), while others were only seen once or a few times. In the latter case, when no match for the observed form was found in the literature, no taxonomic conclusions were drawn.

Vincularia roraimae FučíkOvÁ et KAŠTOVSKÝ was morphologically so distinct from any desmid described so far, and was found in high enough abundance and in all life stages including sexual reproduction, that it was possible to describe it as a new taxon (FuČíKOVÁ \& KAŠTOVSKÝ 2009). V. roraimae occurs abundantly in streams on the summit of Roraima and is peculiar in its production of thick unbranched filaments gro- 


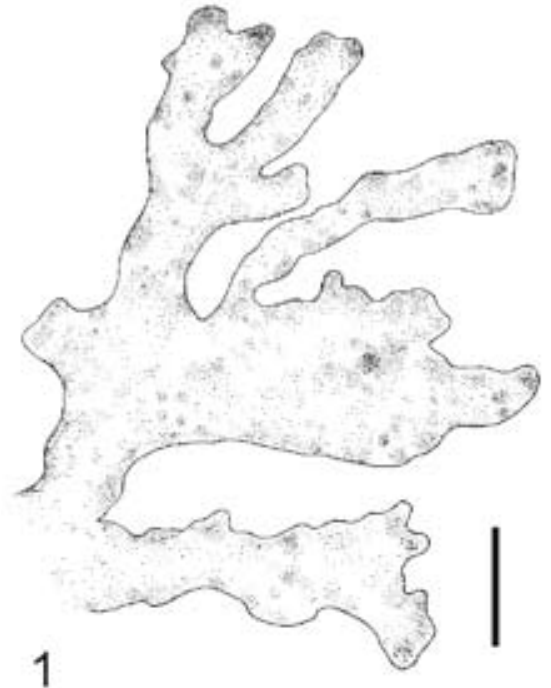

4

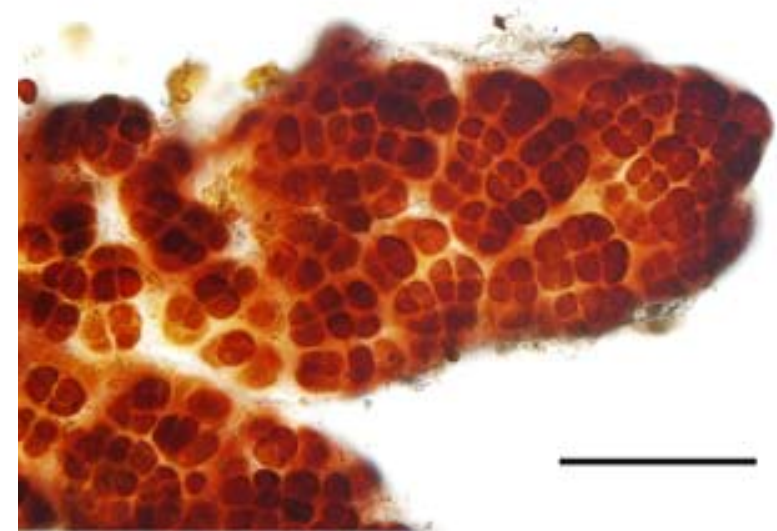

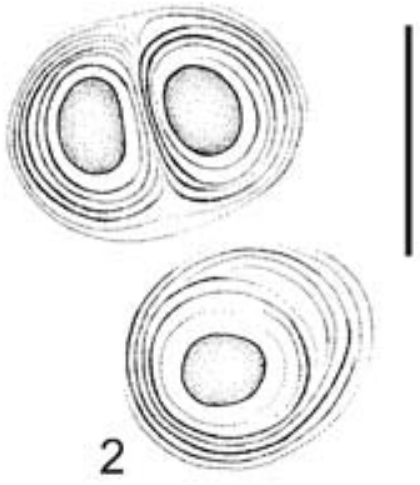
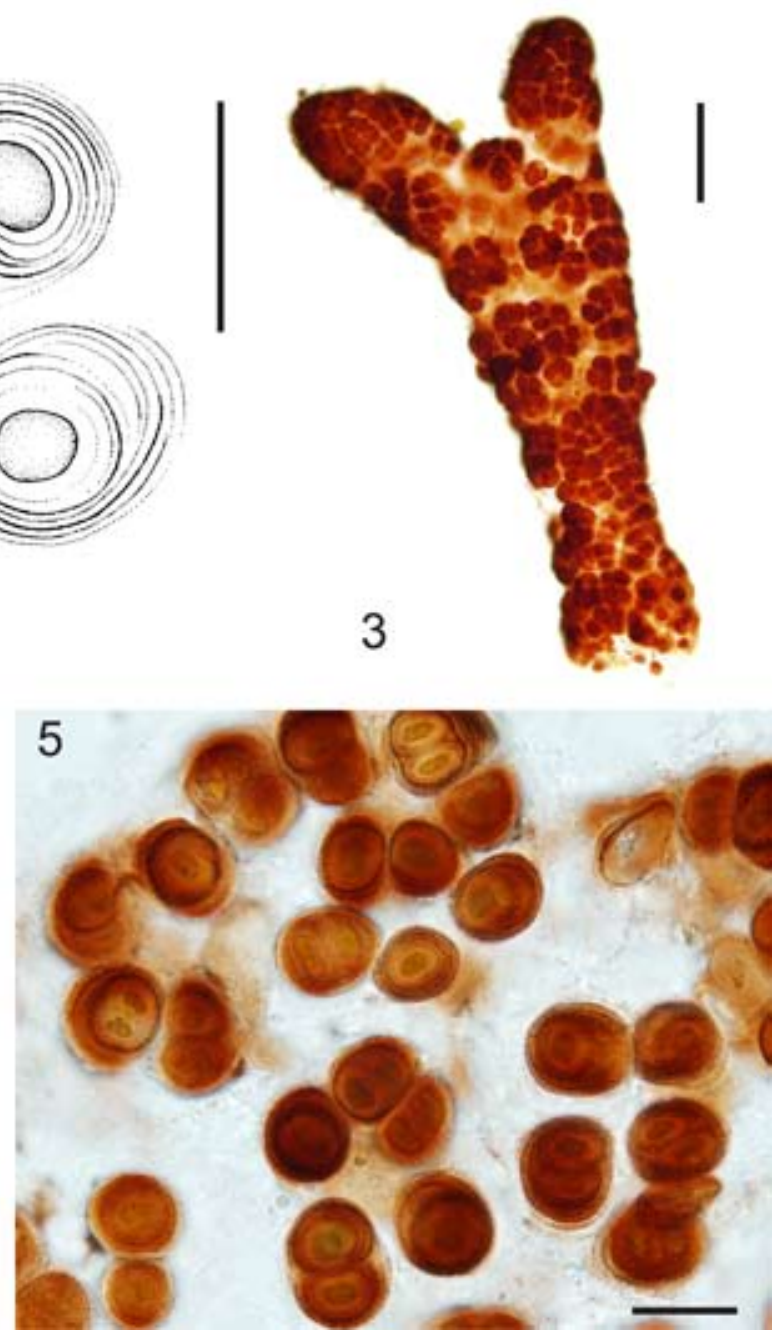

Fig. 3. Entophysalis arboriformis sp. nov. Scale bars $0.5 \mathrm{~mm}(1) ; 20 \mu \mathrm{m}(2,5) ; 100 \mu \mathrm{m}(3,4)$.

wing from each cell (Suppl. Fig. 1/24).

Other desmid taxa observed in the present study were found to differ in some characters from their closest morphological matches in the literature. In some cases this was due to bad physical condition of specimens, a small number of specimens found, or, such as in the case of Actinotaenium cf. diplosporum (P. LUNDELL) TeILING (Suppl. Fig. 1/5), due to the fact that zygospores, which are critical for reliable identification, were not observed. In other cases, desmids found on top of Mt. Roraima differed from described taxa in size, shape, or ecology. Such cases are listed below.

Cosmarium cf. impressulum is a mediumsized desmid that differs from the taxon described by LENZENWEGER (1999) in wall ornamentation and possibly also ecological requirements. C. impressulum Elfving is thought to avoid peat bogs and prefer alkaline environments (Lenzenweger 1999, but contradicted by Coesel \& Meesters 2007 who reports slightly acidic to slightly alkaline habitats) which is not the case on Mt. Roraima. Morphological differences include series of undulations/bumps on the semicell face that are concentric with the marginal undulations in the Roraima form, whereas C. impressulum's semicell face is smooth. Another taxon with interesting ecology is Cosmarium sp.1 (Suppl. Fig. 1/11), which seems to inhabit exclusively vertical rock outcrops. Morphologically, this taxon did not match any species described in the literature used. Similarly, Euastrum sp. 1 (Suppl. Fig. 1/19), a rare taxon collected from a stream, does not match any described taxon. Its overall shape resembles E. intermedium Cleve, but its width is considerably smaller than that of the $E$. intermedium, which is $32-45 \mu \mathrm{m}$ broad, whereas the Euastrum sp 1. from Roraima Tepui is only 27 

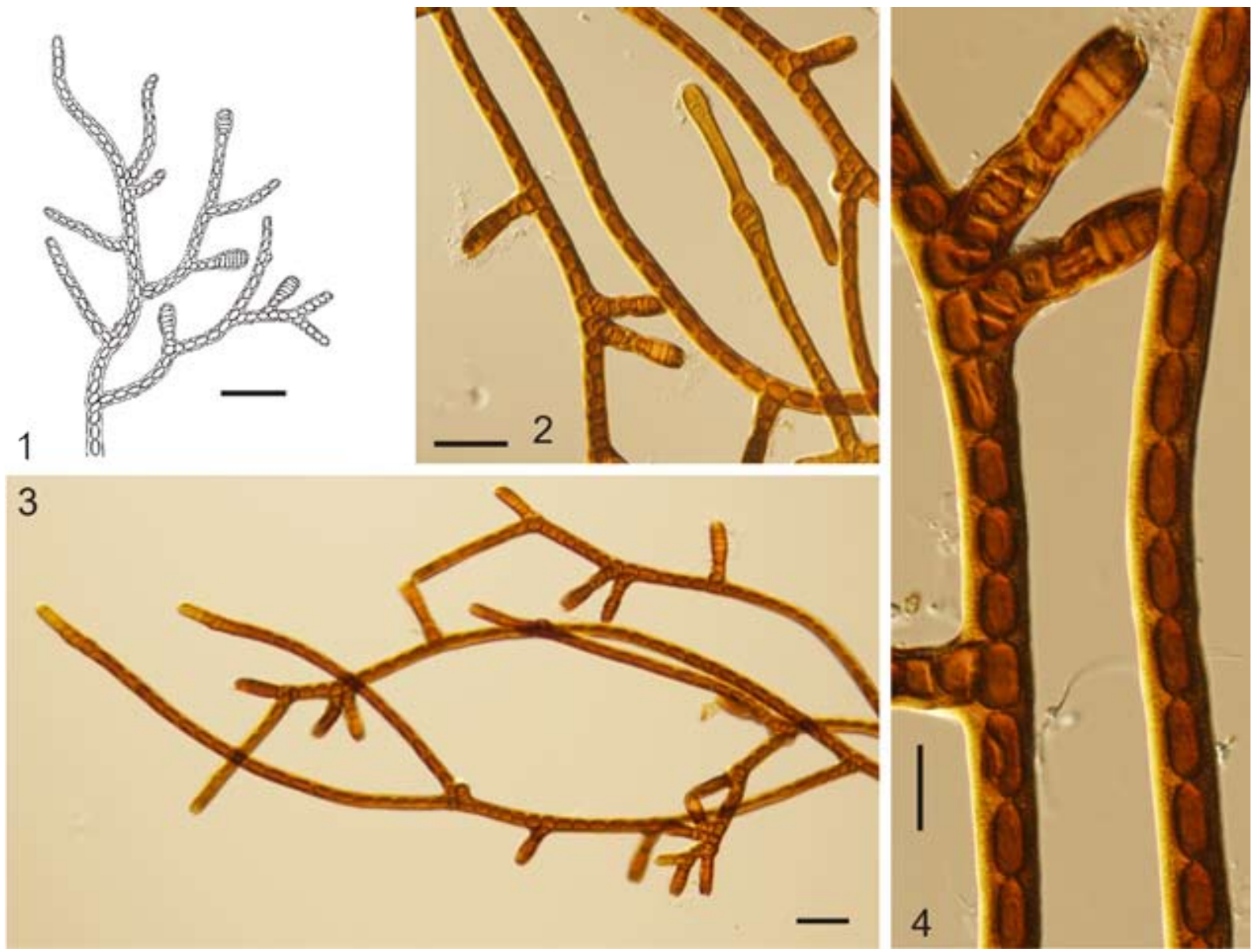

Fig. 4. Albrightia roraimae sp. nov. Scale bars $50 \mu \mathrm{m}(1-3) ; 20 \mu \mathrm{m}$ (4).

$\mu \mathrm{m}$ broad. Species reported in the present study as Staurastrum cf. quadrispinatum (Suppl. Fig 2/17) differs from $S$. quadrispinatum W.B. TURNER by its much more deeply incised median constriction. Staurastrum cf.teliferum (Suppl.Fig. 2/18) exceeds considerably the size of $S$. teliferum RaLFs, but matches it otherwise in morphology and ecology. The spines of Staurodesmus cf. calyxoides (Suppl. Fig. 2/11) are about half the length of those of $S$. calyxoides (Wolle) Croasdale. However, this difference may not be a taxonomically important one because of the great morphological variability generally observed in tropical desmids and even among the specimens observed in Roraima samples. A similar species, Staurodesmus cf. wandae (Suppl. Fig. 2/12-14), differs from the previous taxon in its smaller size $(19.75 \times 22.22$ $\mu \mathrm{m}$ for $S$. cf. wandae vs. $30 \times 35-37 \mu \mathrm{m}$ for $S$. cf. calyxoides) and penta- or less commonly heptaradial symmetry when viewed apically $(S$. cf. calyxoides is always hexaradial). It is possible that the two forms represent intraspecific variation of a single taxon. Staurodesmus sp. does not match any taxon described in the available literature sources. It resembles Ichthyocercus longispinus (Borge) Krieger (Suppl. Fig. 2/5,6 ) somewhat, but lacks any prominent cell wall ornamentation and is mostly triradiate (but considerably variable in shape), whereas $I$. longispinus is described as biradiate. None of the taxa mentioned above have been described as new to science because of the insufficient amount of material for a credible circumscription.

\section{Bacillariophyceae}

The most diverse group of photosynthetic microorganisms found on top of Mt. Roraima were diatoms (Bacillariophyceae), represented by 96 taxa. However, the total biomass was negligible, as only 8 species reached more than $1 \%$ of the total sample biomass in some samples (see Suppl. Table 1). An overview of diatoms found on Roraima is presented in Supplementary Figures 3 and 4 (electronic version only at http:// fottea.czechphycology.cz)

Species that were in some samples 
Fig. 5. CCA analysis: (ACTCUC) Actinotaenium cucurbita; (ACTSUB) Actinotaenium cf. subpalangula; (ASTDIV) Asterocapsa cf. divina; (BACGRA) Bacularia cf. gracilis; (COSCON) Cosmarium cf. contractum; (COSOBT) Cosmarium obtusatum; (COSSP1) Cosmarium sp.1; (CRTURI) Chroococcus cf. turicensis; (CYLGEM) Cylindrocapsa geminella; (ENSSP1) Encyonopsis sp.1; (EUAHUM) Euastrum humbertii var. brasiliense; (EUASBB) Euastrum subbinale; (EUASP1) Euastrum sp.; (EUNSP2) Eunotia sp. 2; (GLEATR) Gloeocapsa cf. atrata; (GLEBIF) Gloeocapsa biformis; (GLEKUT) Gloeocapsa kuetzingiana; (GLEPUN) Gloeocapsa punctata; (GLERUP) Gloeocapsa rupicola; (GLESAN) Gloeocapsa sanguinea; (ENTARB) Entophysalis arboriformis; (GLTSP1) Gloeothece sp. 1; (HAPLUT) Hapalosiphon cf. luteolus; (HOMJUL) Homeothrix cf. juliana; (ICHLON) Ichtyocercus longispinus; (LEPSCH) Leptolyngbya cf. schmidlei; (MICSP1) Microspora sp.1; (MICSP2) Microspora sp.2; (MOUSP1) Mougeotia sp. steril 1; (MOUSP2) Mougeotia sp. steril 2; (NAVRHY) Navicula rhynchocephala; (OEDSPE) Oedogonium sp.; (PLALAN) Planothidium lanceolatum; (PORNOT) Porphyrosiphon cf. notarisii var. minor; (SCHLUT) Schizothrix lutea; (SCHTEL) Schizothrix cf. telephoroides; (SPHSPE) Sphaerococcomyxa sp.; (STAQUA) Staurastrum cf. quadrispinatum;

(STDEXT) Staurodesmus extensus; (STIINF) Stigonema informe; (STIMES) Stigonema cf. mesentericum; (STITOM) Stigonema tomentosum; (TRESPE) Trentepohlia sp.; (UCHROO) unidentified Chroococcales; (VINROR) Vincularia roraimeae; (XENKER) Xenotholos cf. kernerii; (ZYGOGO) Zygogonium sp. steril; (ZYGSP1) Zygnema sp. steril 1.

represented by more that 10 frustules and thus can be rated as relatively abundant and characteristic for the locality were: Eunotia acutuariola LANGEBertalot (Suppl. Fig. 3/1), Eunotia fennica (Hustedt) Lange-Bertalot (Suppl. Fig. 3/2), Encyonopsis sp. 1 (Suppl. Fig. 3/11), Encyonema sparsipunctatum KRAMMER (Suppl. Fig. 3/12), Brachysira rostrata (KRASSKe) Metzeltin et Lange-Bertalot (Suppl. Fig. 4/1), Brachysira serians (BRÉBISSON ex KüTZING) Round et MANN (Suppl. Fig. 4/2), Brachysira sp. 1 (Suppl. Fig. 4/3), Frustulia altimontana Metzeltin et Lange-Bertalot, Frustulia pararhomboides var. pararhomboides LANGE-BERTALOT (Suppl. Fig. 4/9), Frustulia undosa Metzeltin et LangeBertalot (Suppl. Fig. 4/10), and Kobayasiella cf. micropunctata (Suppl. Fig. 4/12).

We also identified some typical South American taxa, which were recently described from the area: Actinella subperonoides (Suppl. Fig. 3/7; Metzeltin \& Lange-Bertalot 2007: plates 44, 45, 46), Amphora sp. (Suppl. Fig. 3/10; Metzeltin \& Lange-Bertalot 1998: tafel 145/8, 9), Brachysira rostrata (Metzeltin \& LANGe-BerTALOT 2007: plate 101/1-7),
Encyonema sparsipunctatum (KRAMMER 1997, tafel 95/1-5), Eunotia acutuariola (MetzeltiN \& Lange-Bertalot 1998: tafel 44/2-8), Eunotia fennica (Metzeltin \& LANGe-Bertalot 2007: Plate 91/1-8) Encyonopsis buhriana, Metzeltin \& Lange-Bertalot 2007: plate 202/11-13), Eunotia cf. geniculata (Suppl. Fig. 3/5; Metzeltin \& Lange-Bertalot 2007: plate 67/3,4), Eunotia noerpeliana (Suppl. Fig. 3/3; Metzeltin \& Lange-Bertalot 1998: tafel 59/1-6, Metzeltin \& Lange-Bertalot 2007: plate 99/3), Fragilarioforma spinulosa (Suppl. Fig. 4/15; Metzeltin \& Lange-Bertalot 2007: plate 20), Frustulia altimontana (Metzeltin \& Lange-Bertalot 1998: tafel 113/1-5), Frustulia pararhomboides var. pararhomboides (METZELTIN \& LANGE-Bertalot 1998: tafel 114/1-9), and Kobayasiella cf. micropunctata (MeTZeLTin \& Lange-Bertalot 1998: tafel 94/10,11; Metzeltin \& LANGe-BeRTALOT 2007: plate 143/11-17).

Some species fit into worldwide distributed diatom taxa, some possessed slight morphological or ecological differences and were assigned to a species with uncertainty (labelled cf.), and others did not fit into any known taxon. Many of those 
belonging to the third category likely deserve to be described as new species (especially in the genus Eunotia, in which 9 unknown taxa were recognized - see Suppl. Fig. 3, and Brachysira with 4 unidentified species), but this would require more thorough examination of the material using SEM, which is beyond the scope of the present study.

The high number of diatom taxa identified from our samples might not in reality reflect the current species richness of diatoms living on the top of Roraima. This is due to the standard method used for species identification in which only diatom frustules without living content (and any other organic material) are observed (see Materials and Methods). After the cell's death, the extremely stable siliceous cell wall can persist on site for years. This phenomenon is likely pronounced in the aerial and standing water habitats abundant on Mt. Roraima, in which there is low chance of old material being removed. Therefore, the taxa listed in Suppl. Table 1 consist of both currently flourishing species and species common in the past and now possibly extinct on the locality.

\section{Other groups}

Other major taxonomic groups of algae occurred rarely and were represented only by 7 species in the case of Chlorophyceae (most abundant species was Cylindrocapsa geminella Wolle), 1 species of Rhodophyta (Batrachospermum sp.) in creeks, and a rare occurrence of 1 Dinophyta species (Gloeodinium sp.) on wet walls. Ecologically interesting is the occurrence of Euglena sp. in the digestive liquid inside the insect trap of the carnivorous plant Brocchinia reducta.

\section{Statistical analysis of species distribution by habitats}

In the CCA ordination based on microvegetation community composition, locality types were used as explanatory variables (Fig. 5). The significance of their effect was supported by a Monte Carlo permutation test $(999$ permutations, $\mathrm{F}$-ratio $=$ $3.476, \mathrm{P}-$ value $=0.0010$ ). The first and second axes account for 4.5 and $2.9 \%$ variability in species data, respectively.

Species only occurring in a single sample were excluded from the analysis (this was a common case in some diatoms and desmids). One of the excluded samples was 2000/37, which contained a single species, Batrachospermum sp. found in a stream.
At the examined localities, several dominant cyanobacterial species occurred abundantly in all habitat types (Gloeocapsa sanguinea, Stigonema ocellatum, S. hormoides, S. informe KütZING). Diatoms were generally found in very low biomass; taxa occurring in most habitat types and more often than only as sporadic solitary frustules were Brachysira rostrata, B. serians, Kobayasiella cf. micropunctata, and Navicula rhynchocephala KüTzING. Among desmids, the most frequent taxa were Actinotaenium cucurbita, Micrasterias arcuata, and Staurastrum pseudozonatum var. minutissimum FöRSTER, all of which also occurred in all habitat types except waterfalls and overhangs. Green filamentous algae were represented by a smaller number of taxa (esp. Mougeotia, Zygogonium, Microspora, and Cylindrocapsa geminella), but in habitats with larger amounts of water (peatbogs, streams, waterfalls and some rock pools) their biomass was fairly high. Below summarized results clearly demonstrate that differences in microhabitat types have great influence on species composition of algal communities.

Overhangs: CCA showed overhangs as the most divergent locality type, likely due to colonization by shade-tolerant organisms that do not occur elsewhere. In contrast to other localities, no desmids were found on overhangs. Gloeocapsa sanguinea, which occurred in all biotopes as one of the dominants, was found to be the main dominant species on overhangs. Gloeocapsa punctata NäGELI, a taxon rarely found in other habitats was very common here, as were Gloeocapsa kuetzingia$n a$ NÄGELI and a green coccoid Sphaerococcomy$x a$ sp. Trentepohlia sp. occurred exclusively in this type of habitat. Overhangs also harbor the widest spectrum of habitat-specific diatoms (found in no other habitat type): Anomoeoneis sp., Caloneis sp., Aulacoseira cf. alpigena, Cyclostephanos dubius (Hustedt) Round, Eunotia cf. geniculata, Eunotia paludosa Grunow, Eunotia sp. 4, Eunotia sp. 5, Eunotia sp. 6, Gomphonema cf. bohemicum ssp. angustiminus, Luticola sp., and Peronia sp. 2. However, all of the above listed diatoms were found only in one sample and in very low relative abundances (mostly a single frustule per species), and therefore no strong conclusions can be drawn. Detrended correspondence analysis (DCA, data not shown) corroborated the most divergent character of overhangs. This analysis also emphasized the partial specificity of waterfalls, streams and peat bogs more than the CCA. The partial similarity 
of waterfalls, streams and peat bogs (somewhat surprising in the case of peat bogs) is caused by the abundance of large filamentous algae, which are much more rare in other habitats (see above). Each of these three locality types harbours a specific algal community (see below).

Waterfalls: Almost no desmids were found in waterfalls (Actinotaenium cucurbita was present in three samples, $A$. cf. cucurbita f. minus in one sample, Netrium oblongum (DE BARY) LÜTKEMÜLLER in one sample, all in relative abundance 1) with the exception of Vincularia roraimeae, which reached relative abundance of 4 in one sample; the cyanobacterium Homeothrix cf. juliana occurred exclusively and in high abundance here and in one stream sample. The cyanobacterium Gloeocapsa cf. atrata, the rare cyanobacterium Bacularia cf. gracilis, and the diatom Frustulia pararhomboides var. pararhomboides LANGEBERTALOT were found exclusively in this habitat, reaching high abundances in some samples. The otherwise common Stigonema informe did not inhabit waterfalls; similarly, the widespread Schizothrix cf. telephoroides was rather rare here (one sample, relative abundance 4). Gleocapsa sanguinea, which was dominant in other habitats, had the least representation in waterfalls.

Streams: The cyanobacterium Schizothrix lutea FRÉMY, the diatom Navicula rhynchocephala, desmids Actinotaenium cf. subpalangula, Vincularia roraimeae, Cosmarium obtusatum (Schmidle) Schmide, and the rhodophyte Batrachospermum sp. were the taxa most tied to this habitat type.

Peat bogs: Hapalosiphon cf. luteolus was abundant here but avoided other locality types. All members of the genus Chroococcus found on Mt. Roraima also occurred most frequently in peat bogs. The highest diversity of desmids was found here, the most abundant being Actinotaenium cf. diplosporum. Also the biomass of Eunotia fennica (Hustedt) Lange-Bertalot was pronouncedly higher in bogs than anywhere else.

The second subgroup of similar localities (in both CCA and DCA) comprises of rock pools, vertical rocks and horizontal rocks. Cyanobacteria that typically occurred in these biotopes were Asterocapsa cf. divina, Porphyrosiphon cf. notarisii, and Schizothrix cf. telephoroides (also present, although in lower abundance, in half of bog samples). Actinotaenium cucurbita, a generally common taxon, was the most abundant here. Again, despite their overall similarities, each of the three habitat types harboured its own characteristic algal community.

Horizontal rocks: The dominant and ubiquitous Stigonema ocellatum reached its maximum abundance in this habitat, along with its epiphyte Xenotholos cf. kernerii. The otherwise very rare diatom Eunotia acutuariola LANGE-BERTALOT was fairly common here (three samples, rel. abundance 2 and 3); Pinnularia cf. transversiformis and Stauroneis phoenicenteron (NitzsCh) Ehrenberg occurred here as well (and also, but less frequently, on vertical rocks)

Rock pools: With the exception of Brachysira serians (one sample, rel. abundance 1), no diatoms were found in this habitat type. All common desmid species and Zygogonium sp. were relatively abundant here.

Vertical rocks: The otherwise rare Gloeocapsa rupicola KüTZING was abundant here (to a limited extent, some horizontal rock samples were also rich in this species). Seven diatom species were only found in this habitat, but only as single frustules: Navicula tenelloides HustedT and especially Nitzschia - N. acicularis (KüTZING) W.Smith, $N$. cf. amphibia, $N$. cf. paleacea, $N$. palea (KÜtZING) W.Smith, N. pusilla Grunow and N. sp.1.

\section{Previous studies on tepuis}

There are not many works we can compare our results with, as due to their limited accessibility, tepuis have received little phycological attention to date. Only three studies have been published on this topic, none of them floristically exhaustive. Gloeocapsasanguinea, Schizothrixsp.,Petalonema (Scytonema) crassum (NäGELI in KützING ) Migula, Scytonema ocellatum (Dillwyn) Lyngbye ex Bornet et Flahault, Stigonema hormoides, Stigonema ocellatum, and Xenococcus sp. were reported in the study by LAKATOS et al. (2001) from Roraima Tepui, but this paper focused on caroteniod composition, not on detailed floristics. Stigonema ocellatum, St. minutum Hassall ex Bornet et Flahault, Gloeocapsa sanguinea, and Schizothrix telephoroides were reported from the blackish-red sandstone rock surface of Serrania Paru Tepui (Büdel et al. 1994). In a 1999 study, Gloeocapsa rupicola, Scytonema ocellatum and Xenococcus sp. were added to the species list (BÜDEL 1999). On "felt-like crusts on part of rock where soil formation took place" Zygogonium sp. was found along with St. ocellatum (BüDEL et al. 1994). The genus Stigonema was reported as the 
overall dominant for this tepui.

B. Büdel also investigated Auyan Tepui and found Gloeocapsa sanguinea (dominant in reddish-coloured areas), Chroococcus sp., Plectonema sp., Stigonema hormoides, St. ocellatum, St.panniforme Bornet et FlaHAULt, and Scytonema crassum (the last three were dominant in blackish-green areas) (BÜDEL 1999). In a later study, Lakatos et al. (2001) added Scytonema hoffmani Agardh ex Bornet et Flahault, Sc. myochrous (Dillwyn) C. Agardh ex Bornet et FlaHAUlt and Stigonema mamillosum AgardH ex Bornet et Flahault to the species list.

Partial information on algal flora is available from Kukenán Tepui, where rock walls were dominated by Gloeocapsopis sp., Chondrocystis sp., and Stigonema spp., and bogs were inhabited by Zygnematales as well as the genera Stigonema and Scytonema (PoKORNÝ 1996).

Any meaningful comparison of these less detail-rich floristic studies with our results is problematic. However, our overall conclusions are similar and the observed taxa and dominants mostly agree with these studies. Interestingly, according to published results, the most divergent flora was found on the closely adjacent Kukenán, but a comparable detail-focused study of Kukenán would be required to address this issue properly.

\section{On the endemism of microorganisms}

The question whether or not endemic species exist in algae and cyanobacteria is not an easy one to discuss. Considerable complications bring the fact that the real biogeography of microorganisms is not as well understood as that of larger organisms (e.g., vascular plants), particularly in regions more difficult to research than the North Temperate Zone (e.g., the tropics) (MANN \& Droop 1996; GIULIETTI et al 2005; ADL et al. 2007), and that the species concept is often not clear even in major groups of algae (e.g. Broady 1996; Vyvermann 1996).

Theoretically, the distribution of algae and cyanobacteria may be viewed from two perspectives. First is a theory of neutral dispersal model (Finlay 2002; Fenchel \& Finlay 2004), which was proposed foreukaryotic microorganisms based on observations of ciliates, and also has been applied to the distribution of bacteria (FINLAY et al. 1999), including cyanobacteria. Based on this theory, e.g., cyanobacteria can be viewed as organisms with cosmopolitan to ubiquitous distribution (CASTENHOLZ 2005) with diversity comprised of a small number of extremely variable entities (RIPPKA et al. 1979; Drouet 1981; Castenholz 2001; Castenholz \& Norris 2005). Presently, only 63 forms (genera) are recognized by main determination source of this school the bacteriological "Bible", Bergey's Manual (CAstenholz 2001).

However, the validity of neutral dispersal model is challenged or at least disputed in case of many other algal groups (e.g., ŘEzÁčovÁ \& Neustupa 2007; Neustupa \& Řezáčová 2007; Coesel \& Krienitz 2008; Kristiansen 2008). If we define ubiquitous species as ones capable of living in any environment on any continent, then there are probably very few of such "weedy" taxa - e.g., Pseudococcomyxa simplex (MaInX) Fotт, or Stichococcus spp. (Novis et al. 2008). A narrower term cosmopolitan species stands for inhabitants of similar kinds of biotopes but different geographic regions. This is often the case in species living in very specific conditions, such as a thermal cyanobacterium Mastigocladus laminosus COHN ex KIRCHNER (KAŠTOVSKÝ \& JOHANSEN 2008). Likely, the most common mode of distribution still in agreement with the neutral dispersal model would be that of the species living in similar habitats and spanning a larger but limited geographic zone (circumpolar, pantropical, etc.). Thus, if the endemism did not exist in microalgae, we should be always able to confirm the occurrence of any taxon in comparable habitats of different locations. However, this seem to not be the case, as majority of the taxonomic studies focused on previously unexplored geographical locations report occurrence of new forms in various algal groups that do not fit any known description: desmids - Coesel, 1996, 2000, 2002, 2003; FuČíKOvÁ \& KAŠTOVSKÝ 2009; green algae - Neustupa \& Š Ejnohová 2003; Neustupa 2005; Stoyneva et al. 2005, 2006; Rindi \& Lopez-Bautista 2008; Cryptophyta - Menezes \& Novarino 2003; Euglenophyta - WydrzyCKA 1996; Dinophyta - CARTY \& WUJEK 2003; TAYLOR et al. 2008; Cyanobacteria-KoMÁreK \& CRONBERG 2001; Komárek 2003; Cronberg \& KomáreK 2004; KomÁreK \& KomÁrKová-LEgnerová 2007; Fiore et al. 2007; MAREŠ et al. 2008; KorelusovÁ et al. 2009; Fleming \& Prufert-Bebout 2010. Moreover, because sexual reproduction is an obligate stage in the life cycle of most diatom species, the neutral dispersal model likely does not apply to this whole group (MANN \& Droop 1996, VyVERMAn et al. 2007, VANORMELINGEN et al. 2008), which is also an evidence standing against general 
adoption of the theory to the microorganisms. Therefore, we accept the "botanical" way of thinking, in cyanobacteria depicted particularly in monographs by KomÁreK \& ANAgnostidis (1998 and 2005), and summarized in the CyanboDB.cz database (KOMÁREK \& HAUER 2010). In this concept, 252 validly described cyanobacterial genera are recognized and endemic species are generally accepted. In agreement with previous knowledge on endemism of other taxonomic groups, endemic species in algae and cyanobacteria tend to occur in isolated areas: Australia (Tyler 1996; Croome et al. 1998; SABBE et al. 2001; D'Archino et al 2010), or islands such as Madagascar (MetzeLTiN \& Lange-Bertalot 2002; Spaulding \& Kociolek 2003; Bixby et al. 2009), New Caledonia (Moser et al. 1998), or Tierra del Fuego (VIGNA \& KRISTIANSEN 1996). If such an area also has extreme ecological conditions, the effect is even more pronounced (Antarctica - VINCENT 2000; DE Wever et al. 2009; RyBalka et al 2009; VAN DE VIJVER et al. 2010).

Mt. Roraima most likely fits the type of locality with high probability of occurrence of endemics - it is very isolated and contains extreme habitats. In many groups of organisms, endemism has been already documented there (see introduction). Therefore, we do not find surprising the fact that species demonstrably new to science were found here, as well as others that did not have a good morphological match in the literature.

\section{Acknowledgements}

Expedition on the Roraima Tepui 2000 was supported by grant of Sigma-Xi. This study was supported by grants MSM 600766 5801, GAJU135/2010/P, AV0Z60050516, and GAČR 206/08/0318. Authors thank all members of our expedition on Roraima, especially Alena Jírová for picture of Mt. Roraima.

\section{References}

Adl, S.M., Leader, B.S., Simpson, A.G.B., Archibald, J.M., Anderson, O.R., Bass, D., Bowser, S.S., Brugellore, G., Farmer, M.A., Karpov, S., Kolisko, M., Lane, C.E., Lodge, D.J., Mann, D.G., Meisterfeld, R., Mendoza, L., Moestrup, O., Mozley-Standridge, S.E., Smirnov, A.V. \& Spiegel, F. (2007): Diversity, nomenclature, and taxonomy of protists. - Syst. Biol. 56: 684-689.

Audy, M. (2008): Brány do ztraceného světa [Gates to a lost World]. - 175 pp., JOTA, Brno.

Bixby, R.J., Benstead, J.P., Douglas, M.M. \& Pringle, C.M.
(2009): Relationships of stream algal community structure to catchment deforestation in eastern Madagascar. - J. N. Am. Benthol. Soc. 28:466-479.

Briceno, H., Schubert, C. \& PAolini, J. (1990): Tablemountain geology and surficial geochemistry. Chimantá Massif, Venezuelan Guyana Shield. - J. S. Am. Earth. Sci. 3: 179-194.

Broady, P.A. (1996): Diversity, distribution and dispersal of Antarctic terrestrial algae. - Biodivers. Conserv. 5: 1307-1335.

Buck, W.R. \& CRum, H. (1993): Notes on Guyana Mosses with new information on Sphagnum ornatum. Brittonia 45: 17-20.

BÜDEL, B. (1999): Ecology and diversity of rock-inhabiting cyanobacteria in tropical regions. - Eur. J. Phycol. 34: 361-370.

Büdel, B. \& LANGE, O.L. (1991): Water status of green and blue.green phycobionts in lichen thalii after hydration by water-vapor uptake - do they became turgid? Botanica Acta 104: 361-366.

Büdel, B., Lüttge, U., Stelzer, R., Huber, O. \& Medina, E. (1994): Cyanobacteria of rocks and soils of the Orinoco lowlands and the Guyana uplands, Venezuela. - Bot. Acta 107: 422-431.

Campbell, J.A. \& Clarke, B.T. (1998): A review of frogs of the genus Otophryne (Microhylidae) with the description of a new species. - Herpetologia 54: 301-317.

CARTY, S. \& WujeK, D.E. (2003): A new species of Peridinium and new records of dinoflagellates and silica-scaled chrysophytes from Belize. - Caribb. J. Sci. 39: 136139.

Casamatta, D.A., Gomez, S. R. \& Johansen, J. R. (2006): Rexia erecta gen. et sp. nov. and Capsosira lowei sp nov., two newly described cyanobacterial taxa from the Great Smoky Mountains National Park (USA). Hydrobiologia 561: 13-26.

Castenholz, R.W. (2001): Cyanobacteria. - In: Boone, D.R., Castenholz, R.W. \& Garrity, G.M. (eds.): Bergey's Manual of Systematic Bacteriology, 2nd Ed. Vol. 1. The Archaea and the Deeply Branching and Phototrophic Bacteria. - pp. 473-597, Springer , New York.

Castenholz, R.W. \& Norris, T.B. (2005) Revisionary concepts of species in the cyanobacteria and their applications. -Algological Studies 117: 53-69.

Coesel, P.F.M. (1996): Biogeography of Desmids. Hydrobiologia 336: 41-53.

Coesel, P.F.M. (2000): Desmids (Chlorophyta, Desmidiaceae) from Thale Noi (Thailand). - Nord. J. Bot. 20: 369383.

Coesel, P.F.M. (2002): Taxonomic and biogeographical notes on Malagassy desmids (Chlorophyta, Desmidiaceae). - Nord. J. Bot. 22: 239-255.

Coesel, P.F.M. (2003): Closterium karnakense spec. nov. and the issue of ecotypic differentiation in desmids. Biologia 58(4): 639-643.

Coesel, P.F.M. \& Krienitz, L. (2008): Diversity and geographic distribution of desmids and other coccoid green algae. - Biodivers. Conserv. 17: 381-392.

Coesel, P.F.M \& Meesters, K.J. (2007): Desmids of the Lowlands. -351 pp., KNNV Publishing, Zeist.

Copeland, J.J. (1936): Yellowstone thermal Myxophyceae. In: Schwartz, H.F. \& Miner E.T. (eds.): The annals of the New York Academy of Science, vol. 36. -232 
pp., The New York Academy, New York.

Cronberg, G. \& Komárek, J. (2004): Some nostocalean cyanoprokaryotes from lentic habitats of Eastern and Southern Africa. - Nova Hedwigia 77-78: 71-106.

Croome, R.L., Kristiansen, J. \& Tyler, P.A. (1998): A description of Mallomonas marsupialis nov. sp. (Synurophyceae), a new chrysophyte from Australia, with comments on endemicity of Australian freshwater algae. - Nord. J. Bot. 18: 633-639.

D’Archino, R., Nelson, W.A. \& Zuccarello, G. C. (2010): Psaromenia (Kallymeniaceae, Rhodophyta): a new genus for Kallymenia berggrenii. - Phycologia 49: 73-85.

De Wever, A., Leliaert, F., Verleyen, E., Vanormelingen, P, Van der Gucht, K., Hodgson, D.A., Sabbe, K.\& VYVERMAN, W. (2009): Hidden levels of phylodiversity in Antarctic green algae: further evidence for the existence of glacial refugia. - P. Roy. Soc. B. Biol. Sci. 276: 3561-3599.

Diels, L. (1914): Die Algen - Vegetation der Südtiroler Dolomitriffe. - Ber. Deut. Bot. Ges. 32: 502-526.

Drouet, F. (1981): Summary of the classification of bluegreen algae. - Nova Hedwigia 66: 133-209.

Fenchel, T. \& Finlay, B.J. (2004): The ubiquity of small organisms: Patterns of global and local diversity. Bioscience 54: 777-785.

FinLAY, B.J. (2002): Global dispersal of free-living microbial eukaryote species. - Science 296: 1061-1063.

Finlay, B.J., Esteban, G.F., Olmo, J.L. \& Tyler, P.A. (1999): Global distribution of free-living microbial species. - Ecography 22: 138-144.

Fiore, M.F., Sant’Anna, C.L., Azevedo, M.T.P., KomÁreK, J., KaštovskÝ, J., Sulek, J. \& LorenZInI, A.S. (2007): The Cyanobacterial genus Brasilonema gen. nov., a molecular and phenotypic evaluation. - J.Phycol. 43: 789-798.

Fleming, E.D. \& Prufert-Bebout, L. (2010): Characterization of cyanobacterial communities from high-elevation lakes in the Bolivian Andes. - J. Geophys. Res. 115: G00D07, doi:10.1029/2008JG000817.

Fölster, H. \& Huber, O. (1984): Interrelaciones Suelos vegetacion en la Area de Galipero, Territorio Federal Amazonas, Venezuela. Serie Informes Tectonicos, DGSIIA/IT/144.

Fölster, H. (1986): Forest savanna dynamics and desertification processes in the Gran Sabana. Interciencia 11: 311-316.

FotT, B. (1954): Pleurax, synthetická pryskyřice pro preparaci rozsivek [Pleurax, a synthetic resin for diatom preparation]. - Preslia 26: 163-194.

FučíkovÁ, K. \& KaŠTovsKÝ, J. (2009): Vincularia roraimae (Zygnematophyceae, Desmidiales), gen. et sp. nov. from the top of Mt. Roraima, Venezuela. - Nova Hedwigia 88: 49-56.

Geitler, L. (1932): Cyanophyceae. - In: Rabenhorst, L. (ed.): Kryptogammenflora von Deutschland, Osterreich, und der Sweitz, Vol.14. - 1056 pp., Akademische Verlagsgesellschaft, Leipzig.

Golubić, S. (1967a): Algenvegetation der Felsen. - In: ElsTER, H.J. \& OHLE, W. (eds.): Die Binnengewässer, Vol. 23.183 pp., E. Schweizerbartsche Verlagsbuchhandlung, Stuttgart.

Golubić, S. (1967b): (1967): Die Algenvegetation an Sandsteinfelsen Ost- Venezuelas (Cumana). - Int. Rev. Ges. Hydrobiol. 52: 693-699.
Giulietti, A.M., Harley, R.M., De Queiroz, L.P., Wanderley, M.D.L. \& VAN DEN BERG, C. (2005): Biodiversity and conservation of plants in Brazil. - Conserv. Biol. 19: 632-639.

Hauer, T. \& PažoutovÁ, M. (2009): Epilitické sinice vybraných lokalit $\mathrm{v}$ Krkonoších Epilithic cyanobacteria in selected localities in the Krkonoše Mts. - Opera Corcontica 46: 57-66

Houk, V. (2003): Atlas of freshwater centric diatoms with a brief key and descriptions - Part 1. Melosiraceae, Orthoseiraceae, Paraliaceae and Aulacoseiraceae. Czech Phycology, Supplement 1: 1-27.

JAAG, O. (1945): Untersuchungen über die Vegetation und biologie der Algen des nackten Gesteins in den Alpen im Jura und im schweizerischen Mittelland. - Beitr. Z. Kryptogamenflora d. Schweiz. 9: 1-560.

Jeffries, D.L., Link, S.O. \& Klopatek, J.M. (1993a): $\mathrm{CO}_{2}$ fluxes of cryptogamic crusts. I. Response of resaturation. - New Phytol. 125: 163-173.

Jeffries, D.L., Link, S.O. \& Klopatek, J.M. (1993b): $\mathrm{CO}_{2}$ fluxes of cryptogamic crusts. II. Response of dehydration. - New Phytol. 125: 391-396.

KAŠTOvskÝ, J. \& JOHANSEN, J.R. (2008): Mastigocladus laminosus (Stigonematales, Cyanobacteria): phylogenetic relationship of strains from thermal springs to soil-inhabiting genera of the order and taxonomic implications for the genus. - Phycologia 47: 307-320.

KaštovskÝ, J., Řeháková, K., Bastl, M., Vymazal, J. \& King, R.S. (2008): Experimental assessment of phosphorus effects on algal assemblages in dosing mesocosms. - In: RichARDSON, C. (ed.): The Everglades Experiments. - pp. 461-476, Springer, New York.

KomÁReK, J. (2003): Two Camptylonemopsis species (Cyanoprokaryotes) from Mata Atlantica in coastal Brazil. - Preslia 75: 223-232.

KomÁreK, J. \& Anagnostidis, K. (1998): Cyanoprokaryota I. - In: Ettl, H., Gärtner, G., Heynig, H. \& Mollenhauer, D. (eds.): Süsswasserflora von Mittleuropa 19/1. - 548 pp., Gustav Fischer, Stuttgart - Jena.

KomÁreK, J. \& ANAGNostidis, K. (2005): Cyanoprokaryota II. -In: Büdel, B., KRIENITZ, L, Gärtner, G. \& SChagerl, M. (eds.): Süsswasserflora von Mittleuropa 19/2. 759 pp., Elsevier/Spektrum, München.

KomÁrek, J. \& Cronberg, G. (2001): Some chroococcalean and oscillatorialean Cyanoprokaryotes from southern African lakes, ponds and pools. - Nova Hedwigia 73: 129-160.

Komárek, J. \& Hauer, T. (2010): CyanoDB.cz - On-line database of cyanobacterial genera. - Word-wide electronic publication, Univ. of South Bohemia \& Inst. of Botany AS CR. http://www.cyanoDB.cz

KomÁreK, J. \& KomÁRKovÁ-LegnerovÁ, J. (2007): Taxonomic evaluation of cyanobacterial microflora from alkaline marshes of northern Belize 1. Phenotypic diversity of coccoid morphotypes. - Nova Hedwigia 84: 65-111.

KorelusovÁ, J., KaštovskÝ, J. \& KomÁreK J. (2009): Heterogeneity of the cyanobacterial genus Synechocystis and description of a new genus Geminocystis. - J. Phycol. 45: 928-937.

Krammer, K. (1997): Die cymbelloiden Diatomeen Teil 1. Allgemeines und Encyonema Part. - In: LANGEBertalot, H. \& Kociolek, P. (eds): Bibliotheca 
diatomologica 36. - 382 pp. , J. Cramer, Berlin, Stuttgart.

Kristiansen, J. (2008): Dispersal and biogeography of silica-scaled chrysophytes. - Biodivers. Conserv. 17: 419-426.

Lakatos, M., Bilger, W. \& Büdel, B. (2001): Carotenoid composition of terrestrial Cyanobacteria: response to natural light conditions in open rock habitats in Venezuela. - Eur. J. Phycol. 36: 367-375.

LANGE, O.L. (1988): Ecophysiology of photosynthesis: performance of poikilohydric lichens and homoiohydric mediterranean sclerophylls. - J. Ecol. 76: 915-937.

Lenzenweger, R. (1999): Desmidiaceenflora von Österreich Vol. 3. - In: Crammer, J. (ed.): Bibliotheca Phycologica 104/3. - 218 pp., Gebrüder Borntraeger Verlagsbuchhandlung, Berlin - Stuttgart.

ManN, D.G. \& Drop, S.J.M. (1996): Biodiversity, biogeography and conservation of diatoms. Hydrobiologia 336: 19-32.

Mareš, J., Kaštovský, J., McGregor, G. \& KomÁrek, J. (2008): The little known pseudofilamentous cyanobacterium Wolskyella (Synechococcales). Nova Hedwigia 87: 221-230.

Menezes, M. \& Novarino, G. (2003): How diverse are planktonic cryptomonads in Brazil? Advantages and difficulties of a taxonomic-biogeographical approach. - Hydrobiologia 502: 297-306.

Metzeltin, D. \& Lange-Bertalot, H. (1998): Tropical Diatoms of South America I. - In: LANGE-BERTALOT, H. (ed.): Iconographia Diatomologica Vol. 5. - 695 pp., Koeltz Scientific Books, Königstein.

Metzeltin, D. \& Lange-Bertalot, H. (2002): Diatoms from the Island Continent Madagascar. - In: LANGEBertalot, H. (ed.): Iconographia Diatomologica Vol. 11. - 286 pp., Koeltz Scientific Books, Königstein.

Metzeltin, D. \& Lange-Bertalot, H. (2007): Tropical Diatoms of South America II. - In: LANGE-Bertalot H. (ed.): Iconographia diatomologica Vol. 18. - 877 pp., Koeltz Scientific Books, Königstein.

Michelangeli, F.A. (2000): Species composition and species-area relationships in vegetation isolates on the summit of a sandstone mountain in southern Venezuela. - J. Trop. Ecol. 16: 69-82.

Moser, G., Lange-Bertalot, H. \& Metzelin, D. (1998): Insel der Endemiten-Geobotanisches Phänomen Neukaledonien. - Bibl. Diatomol. 38: 1-464.

Myers, C.W. \& Donnelly, M.A. (2001): Herpetofauna of the Yutaje-Corocoro massif, Venezuela: Second report from The Robert G. Goelet American Museumterramar expedition to the northwestern tepuis. - B. Am. Mus. Nat. Hist. 261: 1-85.

Neustupa, J. (2005): Investigations on the genus Phycopeltis (Trentepohliaceae, Chlorophyta) from South-East Asia, including the description of two new species. - Cryptogam. Algol. 26: 229-242.

Neustupa, J. \& ŘEzÁČOvÁ, M. (2007): The genus Mallomonas (Mallomonadales, Synurophyceae) in several Southeast Asian urban water bodies - the biogeographic implications. - Nova Hedwigia 84: 249-259.

NeuStuPA, J. \& ŠEJNOHOvÁ, L. (2003): Marvania aerophytica sp. nov., a new subaerial tropical green alga. Biologia 58: 503-507.

Neustupa, J. \& ŠKaloud, P. (2008): Diversity of subaerial algae and cyanobacteria on tree bark in tropical mountain habitats. - Biologia 63: 806-812.

NovÁČEK, F. (1934): Epilithické sinice serpentinů mohelenských. Pars I.: Chroococcales.[Epilithic cyanobacteria of serpentines by Moholeno. Part I.: Chroococcales.] - In: Podpěra, J. (ed.): Mohelno. - 178 pp., Svaz pro ochranu př́rody a domoviny v zemi Moravskoslezské, Brno.

Novis, P.M., Beer, T. \& Vallance, J. (2008): New records of microalgae from the New Zealand alpine zone, and their distribution and dispersal. - N. Z. J. Bot. 46: 347-366.

Perezzapata, A., Lew, D., Aguilera, M. \& Reig, O.A. (1992): New data on the systematics and karyology of Podoxymys roraimae (Rodentia, Cricetidae). $-\mathrm{Z}$. Saugetierkd. 57: 216-224.

PoKornÝ, P. (1996): Tepui. Stolové hory venezuelské Guyany aneb život ve druhém patře [Tepui. Table Mountains of the Venezuelan Guyana alias life in the second floor]. - Vesmír 75: 557-564.

Rindi, F. \& Lopez-Bautista, J.M. (2008): Diversity and ecology of Trentepohliales (Ulvophyceae, Chlorophyta) in French Guiana. - Cryptogam. Algol. 29: 13-43.

Rippka, R., Deruelles, J., Waterbury, J. B., Herdman, M., Stanier, R.Y. (1979): Generic assignments, strain histories and properties of pure cultures of Cyanobacteria. - J. Gen. Microbiol. 111: 1-61.

Rybalka, N., Andersen, R.A., Kostikov, I., Mohr, K., Massalski, A., Olech, M. \& Friedl, T. (2009): Testing for endemism, genotypic diversity and species concepts in Antarctic terrestrial microalgae of the Tribonemataceae (Stramenopiles, Xanthophyceae). Environ. Microbiol. 11: 554-565.

ŘezÁčovÁ, M. \& Neustupa, J. (2007): Distribution of the genus Mallomonas (Synurophyceae) - Ubiquitous dispersal in microorganisms evaluated. - Protist 158: 29-37.

Sabbe, K., Anhoutte, K., Lowe, R.L., Bergey, E.A., Biggs, B.J.F., Francoeur, S, Hodgson, D. \& Vyverman, W. (2001): Six new Actinella (Bacillariophyta) species from Papua New Guinea, Australia and New Zealand: further evidence for widespread diatom endemism, in the Australasian region. - Eur. J. Phycol. 36: 321340.

Spangler, P.J. (1985a): A new genus and species of rifflebeetle Neblinagena prima from the the Tepui Cerro de la Neblina, Venezuela (Coleoptera, Elmidae, Larinae). - P. Entomol. Soc. Wash. 87: 538-544.

SPANGLER, P.J. (1985b): 2 new species of water-striders of the genus Oiovelia from the Tepui Cerro de la Neblina, Venezuela (Hemiptera, Veliidae). - P. Entomol. Soc. Wash. 88: 438-450.

Spangler, P.J. \& Faitoute, R.A. (1991): A new genus and species of neotropical water beetle Jolyelmis auyana from a Venezuelan Tepui (Coleoptera, Elmidae). - P. Biol. Soc. Wash. 104: 322-327.

Spaulding, S. \& Kociolek, J. (2003): Bacillariophyceae, freshwater diatoms. - In: Goodman, S.M. \& BENSTEAD, J.P. (eds): The natural history of Madagascar. - pp. 276-282, University of Chicago Press, Chicago.

Steyermark, J.A., Berry, P.E. \& Holst, B.K. (1995): Flora of the Venezuelan Guyana. - 357 pp., Missouri Botanical Garden, St. Louis.

Steymark, J. (1987): Speciation and endemism in the flora 
on the Venezuelan Tepuis. - In: Vuillemuier, F. \& Monasterio, M. (eds.): Hight altitude biogeography. - pp. 317-373, Oxford University Press, Oxford.

Stoyneva, M.P, Gartner, G. \& Cocquyt, C. (2005): Closteriopsis petkovii - a new green algal species from Lake Tanganyika (Africa). - Phyton - Ann. Rei. Bot. A. 45: 237-247.

Stoyneva, M.P., Gartner, G., Cocquyt, C. \& Vyverman, W. (2006): Eremosphaera tanganyikae sp. nov. (Trebouxiophyceae), a new species from Lake Tanganyika. - Belg. J. Bot. 139: 3-13.

Strobel, G.A., Ford, E., Li, J.Y., Sears, J., Sidhu, R.S. \& Hess, W.M. (1999): Seimatoantlerium tepuiense gen. nov., a unique epiphytic fungus producing taxol from the Venezuelan Guyana. - Syst. Appl. Microbiol. 22: 426-433.

Strobel, G., Hess, W.M., Baird, G., Ford, E., Li, J.Y. \& SiDHu, R.S. (2001): Stegolerium kukenani gen, et sp nov an endophytic taxol producing fungus from the Roraima and Kukenan tepuis of Venezuela. Mycotaxon 78: 353-361.

Taylor, F.J.R., Hoppenrath, M. \& Saldarriaga, J.F. (2008): Dinoflagellate diversity and distribution. - Biodivers. Conserv. 17: 407-418.

ter BraAk, C.J.F. \& Šmilauer, P. (1998): CANOCO reference manual and user's guide to canoco for windows. 352 pp., Microcomputer power, Ithaca.

Tyler, P.A. (1996): Endemism in freshwater algae. Hydrobiologia 336: 127-135.

Van de Vijver B., Mataloni, G., Stanish, L. \& Spaulding, S.A. (2010): New and interesting species of the genus Muelleria (Bacillariophyta) from the Antarctic region and South Africa. - Phycologia 49: 22-41.

Vanormelingen, P., Verleyen, E. \& Vyverman, W. (2008): The diversity and distribution of diatoms: from cosmopolitanism to narrow endemism. - Biodivers. Conserv. 17: 393-405.

Vigna, M.S. \& Kristiansen, J. (1996): Biogeographic implications of new records of scale-bearing chrysophytes from Tierra del Fuego (Argentina). Arch. Protist. 147: 137-144.

VINCENT, W.F. (2000): Evolutionary origins of Antarctic microbiota: invasion, selection and endemism. Antarct. Sci. 12: 374-385.

VyvermanN, W. (1996): The Indo-Malaysian NorthAustralian phycogeographical region revise. Hydrobiologia 336: 107-120.

Vyverman, W., Verleyen, E., Sabbe, K., Vanhoutte, K., Sterken, M., Hodgson, D.A., Mann, D.G., Juggins, S., De Vijver, B.V., Jones, V., Flower, R., Roberts, D., Chepurnov, V.A., Kilroy, C., Vanormelingen, P. \& De Wever, A. (2007): Historical processes constrain patterns in global diatom diversity. Ecology 88: 1924-1931.

Watanabe, M. \& KomÁReK, J. (1994): Several Cyanoprocaryotes from Sagarmatha National Park, Nepal Himalayas. - Bull. Nat.l Sci. Mus. Tokyo Bot. 20: $1-31$.

WYDRZYCKA, U.M. (1996): The species of Trachelomonas (Algas: Euglenophyta) in three volcanic lakes of Costa Rica. - Rev. Biol. Trop. 44: 477-484.

(C) Czech Phycological Society (2011)

Recieved Sept 2010

Accepted Dec 2010

Supplementary material

This material is available as part of the online article (http://fottea.czechphycology.cz/contents)

Table S1. 1 = estimated relative abundance $<0.1 \% ; 2=0.1-1 \% ; 3=1-5 \% ; 4=5-20 \% ; 5=20-50 \% ; 6=50-90 \% ; 7=90-100$ $\%$. Numeric values for frequency in parentheses $=$ species occurred in this frequency in fewer than 3 samples. ST $=$ streams, $\mathrm{WF}=$ waterfals, $\mathrm{PB}=$ peatbogs, $\mathrm{VR}=$ vertical rocks, $\mathrm{HR}=$ horizontal rocks, $\mathrm{RP}=$ rock pools, $\mathrm{OV}=$ overhangs.

*Euglena sp. was found in the digestive liquid inside the insect trap of the carnivorous plant Brocchinia reducta.

\begin{tabular}{lccccccc}
\hline & ST & WF & PB & VR & HR & RP & OV \\
\hline Cyanobacteria & & & & & & & \\
Albrighritia roraimae sp. nov & 0 & 0 & 0 & 0 & $0(3)$ & $0(3)$ & 0 \\
Aphanocapsa cf. muscicola & $0-(3)$ & $0(3)$ & $0-1(3)$ & $0(3)$ & $0(1)$ & $0(1)$ & 0 \\
Asterocapsa cf. divina & $0(3)$ & $0(1-3)$ & $0(1)$ & $0-4$ & $0(1-4)$ & $0(3)$ & $0(1-3)$ \\
Bacularia cf. gracilis & 0 & $0(1)$ & 0 & 0 & 0 & 0 & 0 \\
cf. Cyanokybus & 0 & 0 & 0 & 0 & 0 & 0 & $0(1)$ \\
Cyanothece aeruginosa (NäGELI) KoMÁREK & $0(1)$ & $0(1)$ & $0-1(3)$ & 0 & $0-1$ & $0-1$ & 0 \\
Cyanosarcina sp. & 0 & $0(1)$ & 0 & $0(1)$ & 0 & 0 & 0 \\
Eucapsis alpina ClemENTS et SCHANTZ & 0 & 0 & $0(1)$ & 0 & 0 & 0 & 0 \\
\hline
\end{tabular}


Table S1 Cont.

\begin{tabular}{|c|c|c|c|c|c|c|c|}
\hline $\begin{array}{l}\text { Geitlerinema splendidum (GREVILLE) ANA- } \\
\text { GNOSTIDIS }\end{array}$ & $0(2)$ & $0(2)$ & 0 & 0 & 0 & 0 & 0 \\
\hline Gloeocapsa cf. atrata & 0 & $0-(4)$ & 0 & 0 & 0 & 0 & 0 \\
\hline Gloeocapsa biformis ERCEGOVIĆ & 0 & 0 & 0 & $0-(3)$ & $0-(3)$ & 0 & 0 \\
\hline Gloeocapsa kuetzingiana NäGELI & $0(2)$ & 0 & $0-(3)$ & $0(2)$ & $0-3$ & 0 & $0-5$ \\
\hline Gloeocapsa punctata NÄGELI & 0 & $0-4$ & 0 & $0(3)$ & 0 & $0-3$ & $0-5$ \\
\hline Gloeocapsa rupicola KüTZING & 0 & 0 & $0(3)$ & $2-4(6)$ & $0-3(4)$ & 0 & $0-2(6)$ \\
\hline Gloeocapsa sanguinea (C.AGARDH) KÜTZING & $0-3(4)$ & $0-4$ & $0-5(6)$ & $3-5$ & $\begin{array}{c}(0) 3- \\
4(6)\end{array}$ & $3-5$ & $\begin{array}{l}\text { (0) } 3-5 \\
\text { (7) }\end{array}$ \\
\hline Gloeocapsa arboriformis sp. nov. & 0 & 0 & 0 & $0(4)$ & $0(4)$ & 0 & 0 \\
\hline Gloeothece tepidariorum (BRAUN) LAGERHEIM & 0 & 0 & 0 & 0 & 0 & 0 & $0(2)$ \\
\hline Gloeothece sp. 1 & 0 & 0 & 0 & $0(2)$ & $0(3)$ & 0 & $0-3(4)$ \\
\hline cf. Gomphosphaeria & 0 & 0 & 0 & 0 & $0(2)$ & 0 & 0 \\
\hline Hapalosiphon cf. luteolus & $0(2,3)$ & 0 & $0-4$ & 0 & $0(2)$ & 0 & 0 \\
\hline Heteroleibleinia cf. pusila & $0(1)$ & 0 & 0 & 0 & 0 & 0 & 0 \\
\hline Homeothrix cf. juliana & $0(2)$ & $0-3(5,6)$ & 0 & 0 & 0 & 0 & 0 \\
\hline Chroococcus cf. turgidus & $0(2)$ & $0(2)$ & $0-2(3)$ & 0 & $0(2)$ & $0(2)$ & 0 \\
\hline Chroococcus cf. turicensis & $0(2)$ & $0(2)$ & $0-1(2)$ & 0 & $0(2)$ & 0 & 0 \\
\hline Chroococcus minor (KüTZING) NäGELI & 0 & $0(2)$ & $0(1,2)$ & 0 & 0 & 0 & 0 \\
\hline Chroococcus minutus (KüTZING) NäGELI & $0(1)$ & $0(2)$ & $0(1,3)$ & 0 & $0(2)$ & 0 & 0 \\
\hline Komvophoron cf. schmidlei & $0(2)$ & $0(2)$ & $0(2)$ & $0(2)$ & 0 & 0 & 0 \\
\hline $\begin{array}{l}\text { Leptolyngbya tenuis (GOMONT) ANAGNOSTIDIS } \\
\text { et KoMÁREK }\end{array}$ & $0(2,3)$ & $0(3)$ & $0(3,4)$ & 0 & $0-2(3)$ & $0-2(3)$ & $0(2)$ \\
\hline Leptolyngbya cf. schmidlei & $0(3)$ & $0(3)$ & $0(2)$ & $0-4$ & $0-3$ & 0 & 0 \\
\hline Merismopedia cf. elegans & $0(1)$ & 0 & 0 & 0 & 0 & 0 & 0 \\
\hline Merismopedia glauca (EHRENBERG) KÜTZING & $0(1)$ & 0 & 0 & 0 & 0 & 0 & 0 \\
\hline Porphyrosiphon cf. notarisii var. minor & $0(3)$ & $0(2,5)$ & $0(3)$ & $0-4$ & $0-4(5)$ & $0-2(6)$ & $0-3$ \\
\hline cf. Romeria & 0 & $0(2)$ & $0(2)$ & 0 & 0 & 0 & 0 \\
\hline Scytonema cf. multiramosum & 0 & 0 & 0 & $0(1)$ & $0(3)$ & 0 & 0 \\
\hline Scytonema cf. myochrous & $0(2,3)$ & 0 & $0(2,3)$ & 0 & $0(2-4)$ & $0-4(5)$ & 0 \\
\hline Schizothrix cf. telephoroides & $0(4-6)$ & $0(4)$ & $0-4$ & $\begin{array}{c}(0) \\
2-5(6)\end{array}$ & $0-4(5)$ & $0-4$ & $0-3(4)$ \\
\hline Schizothrix lutea FRÉMY & $\begin{array}{l}(0,4) 5 \\
(6)\end{array}$ & $0(2)$ & $0-4$ & 0 & $0(3,5)$ & $0(2)$ & 0 \\
\hline Stigonema cf. mesentericum & 0 & 0 & $0-3(4)$ & 0 & 0 & $0-2$ & $0(4,5)$ \\
\hline $\begin{array}{l}\text { Stigonema hormoides (KÜTZING) BORNET et } \\
\text { FLAHAULT }\end{array}$ & $\begin{array}{c}0-4 \\
(5,6,7)\end{array}$ & $0-4(5)$ & $0-4(6)$ & $0-4(5)$ & $0-4(5)$ & $0-4(5)$ & $0(2-4)$ \\
\hline Stigonema informe KÜTZING & $0(1-3)$ & 0 & $\begin{array}{c}0-4 \\
(5,6)\end{array}$ & $0-3(4)$ & $0-3$ & $0(2)$ & $\begin{array}{c}0-2 \\
(3,4,5)\end{array}$ \\
\hline $\begin{array}{l}\text { Stigonema ocellatum (Dillwyn) Thuret ex } \\
\text { Bornet et FlaHAUlt }\end{array}$ & $\begin{array}{l}0-3,5 \\
(6)\end{array}$ & $\begin{array}{c}(0-2) \\
4-5(6)\end{array}$ & $0-6$ & $0-5$ & $3-6$ & $3-5(6)$ & $0-3$ \\
\hline $\begin{array}{l}\text { Stigonema tomentosum (KÜTZING) HIERONY- } \\
\text { MUS }\end{array}$ & 0 & 0 & 0 & $0-2(3)$ & $0-2(4)$ & 0 & $0(3)$ \\
\hline Xenotholos cf. kernerii & $0(1)$ & 0 & 0 & $0(1,2)$ & $0-3$ & $0-2$ & 0 \\
\hline unidentified Chroococcales & 0 & $0(3,4)$ & $0-3$ & $0(3)$ & 0 & $0(2)$ & $0(2,5)$ \\
\hline \multicolumn{8}{|l|}{ Bacillariophyceae } \\
\hline Achanthes cf. oblongella & 0 & 0 & 0 & $0(1)$ & $0(1)$ & 0 & 0 \\
\hline Actinella subperonoides LANGE-BERTALOT & 0 & $0(1)$ & 0 & 0 & 0 & 0 & 0 \\
\hline
\end{tabular}


Table S1 Cont.

\begin{tabular}{|c|c|c|c|c|c|c|c|}
\hline Amphora sp. & 0 & 0 & 0 & $0(1)$ & 0 & 0 & 0 \\
\hline Anomoeoneis sp. & 0 & 0 & 0 & 0 & 0 & 0 & $0(1)$ \\
\hline Brachysira brebissonii Ross & 0 & $0(1)$ & $0(1,2)$ & 0 & 0 & 0 & $0(1)$ \\
\hline $\begin{array}{l}\text { Brachysira macroserians METZELTIN et LAN- } \\
\text { GE-BERTALOT }\end{array}$ & $0(2)$ & & $0(1)$ & 0 & 0 & 0 & 0 \\
\hline $\begin{array}{l}\text { Brachysira rostrata (KRASSKE) Metzeltin et } \\
\text { LANGE-BERTALOT }\end{array}$ & $0(2)$ & $0(1)$ & $0(3)$ & $0(3)$ & $0(3)$ & 0 & $0(1)$ \\
\hline $\begin{array}{l}\text { Brachysira serians (BRÉBISSON ex KÜTZING) } \\
\text { RouND et MANN }\end{array}$ & $0(1,2)$ & $0(1)$ & $0-3$ & 0 & $0(1-3)$ & $0(2)$ & $0(1)$ \\
\hline Brachysira sp. 1 & 0 & 0 & $0(2)$ & 0 & $0(1)$ & 0 & $0(1)$ \\
\hline Brachysira sp. 2 & 0 & $0(1)$ & 0 & 0 & 0 & 0 & 0 \\
\hline Brachysira sp. 3 & 0 & $0(1)$ & 0 & 0 & 0 & 0 & 0 \\
\hline Brachysira sp. 4 & 0 & $0(1)$ & 0 & 0 & 0 & 0 & 0 \\
\hline Caloneis sp. & 0 & 0 & 0 & 0 & 0 & 0 & $0(1)$ \\
\hline cf. Aulacoseira alpigena & 0 & 0 & 0 & 0 & 0 & 0 & $0(1)$ \\
\hline cf. Chamaepinnularia & 0 & 0 & $0(1)$ & 0 & 0 & 0 & 0 \\
\hline cf. Hantzschia & 0 & $0(1)$ & 0 & 0 & 0 & 0 & 0 \\
\hline cf. Melosira varians & 0 & 0 & 0 & 0 & $0(1)$ & 0 & 0 \\
\hline cf. Pinnularia acoricola & 0 & 0 & 0 & 0 & $0(1)$ & 0 & 0 \\
\hline cf. Stephanocyclus atomus & 0 & 0 & 0 & $0(1)$ & 0 & 0 & 0 \\
\hline cf. Trybrionella sp. 1 & 0 & 0 & $0(1)$ & 0 & 0 & 0 & 0 \\
\hline Cyclostephanos dubius (Hustedt) Round & 0 & 0 & 0 & 0 & $0(1)$ & 0 & $0(1)$ \\
\hline Diatoma mesodon (EHRENBERG) KÜTZING & 0 & $0(1)$ & 0 & 0 & 0 & 0 & 0 \\
\hline Diploneis sp. & 0 & 0 & 0 & 0 & $0(1)$ & 0 & 0 \\
\hline Encyonema sp. & 0 & 0 & 0 & 0 & 0 & 0 & $0(1)$ \\
\hline Encyonema silesiacum (BLEISCH) MANN & 0 & 0 & 0 & $0(1)$ & $0(1)$ & 0 & 0 \\
\hline Encyonema sparsipunctatum Krammer & 0 & 0 & $0(1)$ & 0 & 0 & 0 & $0(1)$ \\
\hline $\begin{array}{l}\text { Encyonopsis buhriana Metzeltin et LANGE- } \\
\text { Bertalot }\end{array}$ & 0 & 0 & 0 & 0 & $0(1)$ & 0 & 0 \\
\hline Encyonopsis cf. blancheanum & 0 & 0 & $0(1)$ & 0 & 0 & 0 & 0 \\
\hline $\begin{array}{l}\text { Encyonopsis subminuta KRAMMER et REI- } \\
\text { CHARDT }\end{array}$ & 0 & 0 & 0 & $0(1)$ & 0 & 0 & 0 \\
\hline Encyonopsis sp.1 & $0(1,2)$ & $0(1-3)$ & $0(1,2)$ & 0 & 0 & 0 & $0(1)$ \\
\hline Eunotia acutuariola LANGE-BERTALOT & 0 & 0 & $0(1,2)$ & 0 & $0(2-3)$ & 0 & $0(1)$ \\
\hline Eunotia $\mathrm{cf}$ circumborealis & 0 & 0 & $0(1)$ & 0 & 0 & 0 & 0 \\
\hline Eunotia cf. fallax & 0 & 0 & $0(1)$ & 0 & 0 & 0 & 0 \\
\hline Eunotia cf. geniculata & 0 & 0 & 0 & 0 & 0 & 0 & $0(1)$ \\
\hline Eunotia cf. noerpeliana & 0 & 0 & 0 & 0 & $0(1)$ & 0 & 0 \\
\hline Eunotia cf. tenela & $0-1(2)$ & $0(1)$ & $0(2)$ & $0(1)$ & $0(2)$ & 0 & 0 \\
\hline Eunotia fennica (Hustedt) LANGE-BerTALOT & 0 & $0(1)$ & $0(1,2)$ & 0 & $0(1)$ & 0 & $0(1)$ \\
\hline Eunotia gibbosa GRUNOW & 0 & 0 & $0(1)$ & 0 & 0 & 0 & $0(1)$ \\
\hline $\begin{array}{l}\text { Eunotia noerpeliana Metzeltin et LANGE- } \\
\text { BERTALOT }\end{array}$ & 0 & $0(1)$ & 0 & 0 & 0 & 0 & 0 \\
\hline Eunotia paludosa GRUNOW & 0 & 0 & 0 & 0 & 0 & 0 & $0(1)$ \\
\hline Eunotia sp. 1 & 0 & $0(1)$ & 0 & 0 & 0 & 0 & 0 \\
\hline Eunotia sp. 2 & $0-2$ & 0 & 0 & 0 & $0(1)$ & 0 & 0 \\
\hline
\end{tabular}


Table S1 Cont.

\begin{tabular}{|c|c|c|c|c|c|c|c|}
\hline Eunotia sp. 3 & 0 & 0 & 0 & 0 & $0(1)$ & 0 & 0 \\
\hline Eunotia sp. 4 & 0 & 0 & 0 & 0 & 0 & 0 & $0(1)$ \\
\hline Eunotia sp. 5 & 0 & 0 & 0 & 0 & 0 & 0 & $0(1)$ \\
\hline Eunotia sp. 6 & 0 & 0 & 0 & 0 & 0 & 0 & $0(1)$ \\
\hline Eunotia sp. 7 & 0 & 0 & 0 & 0 & $0(1)$ & 0 & 0 \\
\hline Eunotia sp. 8 & 0 & 0 & 0 & 0 & $0(1)$ & 0 & 0 \\
\hline Eunotia sp. 9 & 0 & 0 & 0 & 0 & $0(1)$ & 0 & 0 \\
\hline Fragilaria capucina DesmazIÈRES & 0 & 0 & 0 & 0 & $0(1)$ & 0 & 0 \\
\hline $\begin{array}{l}\text { Fragilarioforma spinulosa (PATRICK) LANGE- } \\
\text { BERTALOT }\end{array}$ & $0(2)$ & 0 & $0(1)$ & 0 & 0 & 0 & 0 \\
\hline $\begin{array}{l}\text { Frustulia altimontana Metzeltin et LANGE- } \\
\text { BERTAlOt }\end{array}$ & 0 & 0 & $0(1)$ & 0 & $0(1)$ & 0 & 0 \\
\hline Frustulia cf. undosa & 0 & 0 & $0(1)$ & 0 & 0 & 0 & 0 \\
\hline $\begin{array}{l}\text { Frustulia pararhomboides var. pararhomboi- } \\
\text { des LANGE-BERTALOT }\end{array}$ & 0 & $0(3)$ & 0 & 0 & 0 & 0 & 0 \\
\hline $\begin{array}{l}\text { Frustulia undosa Metzeltin et LANGE-Ber- } \\
\text { TALOT }\end{array}$ & 0 & $0(1)$ & $0(1)$ & 0 & $0(1)$ & 0 & $0(1)$ \\
\hline Frustulia vulgaris (Thwaites) De TonI & 0 & 0 & 0 & 0 & $0(1)$ & 0 & 0 \\
\hline $\begin{array}{l}\text { Gomphonema cf. bohemicum ssp. angustimi- } \\
\text { nus }\end{array}$ & 0 & 0 & 0 & 0 & 0 & 0 & $0(1)$ \\
\hline Gomphonema gracile EHRENBERG & 0 & 0 & 0 & 0 & $0(1)$ & 0 & 0 \\
\hline $\begin{array}{l}\text { Gomphonema micropus var. micropus LANGE- } \\
\text { BERTALOT }\end{array}$ & 0 & & 0 & 0 & 0 & 0 & 0 \\
\hline Gomphonema parvulum (KÜTZING) KÜTZING & $0(2)$ & 0 & 0 & 0 & $0(1)$ & 0 & 0 \\
\hline Hantzschia amphioxys (EHRENBERG) GRUNOW & 0 & 0 & $0(1)$ & 0 & 0 & 0 & 0 \\
\hline Kobayasiella cf. micropunctata & $0(2)$ & $0(1)$ & $0(2)$ & $0(1)$ & $0(1)$ & 0 & $0(1)$ \\
\hline $\begin{array}{l}\text { Kobayasiella pseudosubtilissima (MANGUIN) } \\
\text { LANGE-BERTALOT et REICHARDT }\end{array}$ & 0 & 0 & $0(1)$ & 0 & 0 & 0 & $0(1)$ \\
\hline Kobayasiella sp. 1 & 0 & 0 & $0(1)$ & 0 & 0 & 0 & 0 \\
\hline Kobayasiella sp. 2 & 0 & 0 & 0 & 0 & $0(1)$ & 0 & 0 \\
\hline $\begin{array}{l}\text { Kobayasiella subtillisima (CLEVE) LANGE- } \\
\text { BERTALOT }\end{array}$ & $0(1)$ & $0(1)$ & 0 & $0(1)$ & $0(1)$ & 0 & 0 \\
\hline Luticola muticopsis (VAN HeURCK) ManN & 0 & 0 & $0(1)$ & 0 & $0(1)$ & 0 & 0 \\
\hline Luticola sp. & 0 & 0 & 0 & 0 & 0 & 0 & $0(1)$ \\
\hline Mastogloia sp. & 0 & $0(1)$ & 0 & $0(1)$ & $0(1)$ & 0 & 0 \\
\hline Navicula cincta (EHRENBERG) RALFS & 0 & 0 & $0(1)$ & 0 & 0 & 0 & 0 \\
\hline Navicula gregaria DoNKIN & $0(2)$ & 0 & 0 & $0(2)$ & $0(1)$ & 0 & 0 \\
\hline Navicula rhynchocephala KÜTZING & $0-2(3)$ & $0(1,2)$ & $0-2$ & $0(1)$ & $0(1,2)$ & 0 & 0 \\
\hline Navicula tenelloides HustedT & 0 & 0 & 0 & $0(1)$ & 0 & 0 & 0 \\
\hline Nitzschia acicularis (KÜTZING) W.SмIтH & 0 & 0 & 0 & $0(1)$ & 0 & 0 & 0 \\
\hline Nitzschia amphibia GRUNOW & 0 & 0 & 0 & 0 & $0(1)$ & 0 & 0 \\
\hline Nitzschia cf. amphibia & 0 & 0 & 0 & $0(1)$ & 0 & 0 & 0 \\
\hline Nitzschia cf. paleacea & 0 & 0 & 0 & $0(1)$ & $0(1)$ & 0 & 0 \\
\hline Nitzschia fonticola (GRUNOw) GRUNOW & 0 & $0(1)$ & 0 & 0 & 0 & 0 & 0 \\
\hline Nitzschia hantzschiana RABENHORST & 0 & 0 & $0(1)$ & 0 & 0 & 0 & $0(1)$ \\
\hline Nitzschia palea (KüTZING) W.SмIтH & 0 & $0(1)$ & 0 & 0 & 0 & 0 & 0 \\
\hline
\end{tabular}


Table S1 Cont.

\begin{tabular}{|c|c|c|c|c|c|c|c|}
\hline Nitzschia pusilla GRUNOw & 0 & 0 & 0 & $0(1)$ & 0 & 0 & 0 \\
\hline Nitzschia sp. 1 & 0 & 0 & 0 & $0(1)$ & 0 & 0 & 0 \\
\hline Nitzschia sp. 2 & 0 & 0 & 0 & 0 & $0(1)$ & 0 & 0 \\
\hline Peronia sp. 1 & 0 & $0(1)$ & 0 & 0 & 0 & 0 & 0 \\
\hline Peronia sp. 2 & 0 & 0 & 0 & 0 & 0 & 0 & $0(1)$ \\
\hline $\begin{array}{l}\text { Planothidium lanceolatum (BRÉBISSON ex } \\
\text { KÜtZING) LANGE-BERTALOT }\end{array}$ & 0 & 0 & 0 & $0(1)$ & $0(1)$ & 0 & 0 \\
\hline Pinnularia $\mathrm{cf}$. sinistra & 0 & 0 & 0 & 0 & $0(1)$ & 0 & 0 \\
\hline Pinnularia cf. transfversiformis & 0 & 0 & $0(1)$ & $0(2)$ & $0(4)$ & 0 & 0 \\
\hline Pinnularia sp. 1 & 0 & 0 & $0(1)$ & 0 & $0(1)$ & 0 & 0 \\
\hline $\begin{array}{l}\text { Stephanocyclus meneghiniana (KÜTZING) } \\
\text { SKABITSCHEVSKY }\end{array}$ & 0 & 0 & 0 & $0(1)$ & $0(1)$ & 0 & 0 \\
\hline $\begin{array}{l}\text { Stauroneis phoenicenteron (NITZSCH) EHREN- } \\
\text { BERG }\end{array}$ & $0(2)$ & 0 & 0 & $0(1)$ & $0(1,4)$ & 0 & 0 \\
\hline Surirella minuta BRÉBISSON & 0 & 0 & 0 & $0(1)$ & $0(1)$ & 0 & 0 \\
\hline Synedra ulna (NITZsch) EHRENBERG & 0 & 0 & 0 & $0(1)$ & $0(1,2)$ & 0 & 0 \\
\hline Trybrionella sp. 2 & 0 & $0(1)$ & 0 & 0 & $0(1,2)$ & 0 & $0(1)$ \\
\hline unidentified centric diatom & 0 & 0 & 0 & $0(1)$ & 0 & 0 & 0 \\
\hline unidentified pennate diatom & 0 & 0 & $0(2)$ & $0(1)$ & 0 & $0(1)$ & 0 \\
\hline \multicolumn{8}{|l|}{ Chlorophyta } \\
\hline Cylindrocapsa geminella WOLLE & $0-4$ & $0-4(5)$ & $\begin{array}{c}0-3 \\
(4-6)\end{array}$ & 0 & 0 & $0(3)$ & $0(2)$ \\
\hline Microspora sp.1 (5-8 um) & $\begin{array}{c}0 \\
(2,4,5,6)\end{array}$ & 0 & $0(3)$ & $0(2)$ & 0 & $0(2)$ & 0 \\
\hline Microspora sp.2(more $10 \mathrm{um})$ & $0,4(7)$ & 0 & $0(3)$ & 0 & 0 & 0 & 0 \\
\hline Sphaerococcomyxa sp. & 0 & 0 & 0 & $0(3)$ & $0(2)$ & $0(2)$ & $0(2,3,5)$ \\
\hline Oedogonium sp. & $0(2,4)$ & 0 & 0 & 0 & 0 & 0 & 0 \\
\hline Trentepohlia sp. & 0 & 0 & 0 & 0 & 0 & 0 & 0,2 \\
\hline \multicolumn{8}{|l|}{ Streptophyta } \\
\hline \multicolumn{8}{|l|}{ Klebsormidiales } \\
\hline Klebsormidium cf. flaccidum & 0 & 0 & $0(2)$ & 0 & 0 & 0 & 0 \\
\hline \multicolumn{8}{|l|}{ Desmidiales } \\
\hline $\begin{array}{l}\text { Actinotaenium cucurbita (BRÉBISSON ex } \\
\text { RALfS) TEILING }\end{array}$ & $0-2$ & $0(1,2)$ & $0-2$ & $0-3(4,5)$ & $0-2(4,5)$ & $\begin{array}{c}0-2 \\
(3,4)\end{array}$ & 0 \\
\hline Actinotaenium cf. cucurbita f. minus & $0(1)$ & $0(1)$ & 0 & 0 & $0(1)$ & $0(1)$ & 0 \\
\hline Actinotaenium cf. diplosporum & $0-1(2)$ & 0 & $\begin{array}{c}0-2 \\
(3,4,5)\end{array}$ & $0-2$ & $0(1,2)$ & $0(1)$ & 0 \\
\hline Actinotaenium cf. globosum & 0 & 0 & $0-1(2)$ & $0(2)$ & $0(2)$ & $0-1$ & 0 \\
\hline Actinotaenium cf. obcuneatum & 0 & 0 & 0 & 0 & $0(1)$ & $0(1)$ & 0 \\
\hline Actinotaenium cf. palangula & 0 & 0 & $0(1)$ & 0 & 0 & 0 & 0 \\
\hline Actinotaenium cf. subpalangula & $0(2,3,4)$ & 0 & 0 & 0 & 0 & $0(1,2)$ & 0 \\
\hline Cosamrium cf. contractum & $0(1,2)$ & 0 & $0-1(2,3)$ & 0 & 0 & 0 & 0 \\
\hline Cosmarium cf. impressulum & $0(1)$ & 0 & $0(1,2)$ & 0 & 0 & 0 & 0 \\
\hline Cosmarium cf. laeve & $0-1$ & 0 & $0(1)$ & 0 & $0-1$ & $0(1,2)$ & 0 \\
\hline Cosmarium cf. regneli & $0(1)$ & 0 & 0 & 0 & 0 & 0 & 0 \\
\hline Cosmarium obtusatum (SCHMidLe) SchmidLe & $0-1(2)$ & 0 & $0-1$ & 0 & 0 & 0 & 0 \\
\hline Cosmarium sp.1 & $0-1$ & 0 & 0 & 0 & 0 & 0 & 0 \\
\hline
\end{tabular}


Table S1 Cont.

\begin{tabular}{|c|c|c|c|c|c|c|c|}
\hline Cosmarium sp. 2 & 0 & 0 & $0(1)$ & 0 & 0 & 0 & 0 \\
\hline Cosmarium sp. 3 & $0(1)$ & 0 & $0(1,2)$ & 0 & 0 & 0 & 0 \\
\hline $\begin{array}{l}\text { Cosmarium tinctum var. intermedium NORD- } \\
\text { STEDT }\end{array}$ & $0(1)$ & 0 & 0 & 0 & 0 & 0 & 0 \\
\hline Euastrum humbertii var. brasiliense FÖRSTER & $0(2)$ & 0 & $0(1,2)$ & $0(2)$ & 0,2 & 0 & 0 \\
\hline Euastrum macrocephalum FöRSTER et ECKERT & $0(1)$ & 0 & 0 & $0(1)$ & $0(1)$ & 0 & 0 \\
\hline Euastrum sublobatum BRÉBISSON ex RALFS & $0(1,2)$ & 0 & $0(2,3)$ & $0(1,2)$ & 0 & 0 & 0 \\
\hline Euastrum subbinale GUTWINSKI & $0(1)$ & 0 & 0 & 0 & 0 & 0 & 0 \\
\hline Euastrum sp. & $0-1$ & 0 & 0 & 0 & 0 & 0 & 0 \\
\hline Ichtyocercus longispinus (BORGE) KRIEGER & $0-1$ & 0 & $0(1)$ & 0 & $0(1)$ & $0(1)$ & 0 \\
\hline Micrasterias arcuata BAILEY & $0(1,2)$ & 0 & $0-3$ & $0-1(2)$ & $0(1)$ & $0(1)$ & 0 \\
\hline Netrium oblongum (DE BARY) LÜTKEMÜLLER & 0 & $0(1)$ & $0-1(2)$ & 0 & $0(1,2)$ & $0(1,2)$ & 0 \\
\hline Staurastrum cosmarioides NORDSTEDT & $0(1)$ & 0 & $0(1)$ & $0(1)$ & 0 & 0 & 0 \\
\hline Staurastrum elongatum BARKER & 0 & 0 & $0-1$ & 0 & 0 & 0 & 0 \\
\hline Staurastrum cf. quadrispinatum & $0(1,2)$ & 0 & $0-1(2)$ & 0 & 0 & 0 & 0 \\
\hline Staurastrum cf. teliferum & 0 & 0 & $0-1(2)$ & 0 & 0 & 0 & 0 \\
\hline Staurastrum hystrix RALFS & 0 & 0 & $0-1$ & 0 & 0 & 0 & 0 \\
\hline $\begin{array}{l}\text { Staurastrum pseudozonatum var. minutissi- } \\
\text { mum FÖRSTER }\end{array}$ & $0(1)$ & 0 & $0-2(3)$ & $0(1,2)$ & $0-1(2)$ & $0(1,2)$ & 0 \\
\hline Staurodesmus cf. calyxoides & 0 & 0 & $0(1,2)$ & 0 & $0(2,3,5)$ & $0(2)$ & 0 \\
\hline Staurodesmus cf. wandae & $0(1)$ & 0 & $0-2$ & 0 & 0 & 0 & 0 \\
\hline Staurodesmus extensus (BorgE) TEILING & $0(1)$ & 0 & $0-1$ & 0 & 0 & 0 & 0 \\
\hline Staurodesmus omearii (ARCHER) TEILING & $0(1,2)$ & 0 & $0-2$ & 0 & $0(2)$ & $0-1(2)$ & 0 \\
\hline Staurodesmus sp. & $0(1)$ & 0 & $0-2$ & 0 & 0 & 0 & 0 \\
\hline Tetmemorus laevis KüTZING ex RALFS & 0 & 0 & 0 & 0 & 0 & $0(1)$ & 0 \\
\hline Vincularia roraimeae FučíKovÁ et KAŠTOVSKÝ & $\begin{array}{c}0 \\
(1,2,3,6)\end{array}$ & $0(4)$ & 0 & 0 & 0 & 0 & 0 \\
\hline \multicolumn{8}{|l|}{ Zygnematales } \\
\hline Mougeotia sp. steril 1 & $0,3,4(5,6)$ & $0,3(5,6)$ & $0(2,3,5)$ & $0(4)$ & $0(3)$ & $0(4)$ & 0 \\
\hline Mougeotia sp. steril 2 & $0(5)$ & $0,4(5)$ & 0 & 0 & 0 & 0 & \\
\hline Zygnema sp. steril 1 & $0(3,4)$ & 0 & 0 & $0(4)$ & 0 & 0 & 0 \\
\hline Zygnema sp. steril 2 & $0(4)$ & 0 & 0 & 0 & 0 & 0 & 0 \\
\hline Zygogonium sp. steril & $0(4,5,6)$ & $0,4,5(3)$ & $\begin{array}{c}0,4 \\
(3,5,7)\end{array}$ & $0(3)$ & $0(2)$ & $0(4,5)$ & 0 \\
\hline \multicolumn{8}{|l|}{ Dinophyta } \\
\hline Gloeodinium sp. & 0 & 0 & $0(2)$ & 0 & 0 & & 0 \\
\hline \multicolumn{8}{|l|}{ Euglenophyta } \\
\hline Euglena sp. & 0 & 0 & $0^{*}$ & 0 & 0 & 0 & 0 \\
\hline \multicolumn{8}{|l|}{ Rhodophyta } \\
\hline Batrachospermum sp. & $0(7)$ & 0 & 0 & 0 & 0 & 0 & 0 \\
\hline
\end{tabular}


Fig. S1: Desmids I: (1) Cylindrocystis brebissonii; (2) Mesotaenium endlicherianum; (3) Netrium digitus; (4) Actinotaenium cucurbita; (5) Actinotaenium cf. diplosporum; (6): Actinotaenium cf. lobosum; (7) Actinotaenium cf. subpalangula; (8) Actinotaenium cf. obcuneatum; (9) Cosmarium cf. pseudobengalense; (10) Cosmarium obtusatum; (11) Cosmarium sp.1.; (12) Cosmarium cf. laeve; $(13,14)$ Actinotaenium cf. cucurbita f. minus; (15) Cosmarium tinctum var. intermedium; (16) Cosmarium regnelli; (17) Cosmarium sp.2.; (18) Cosmarium sp.3.; (19) Euastrum sp. 1.; (20) Euastrum sublobatum; (21) Euastrum subbinale; (22) Euastrum macrocephalum; (23) Euastrum humbertii var. brasiliense; (24) Vincularia roraimae. Scale bar $10 \mu \mathrm{m}$.

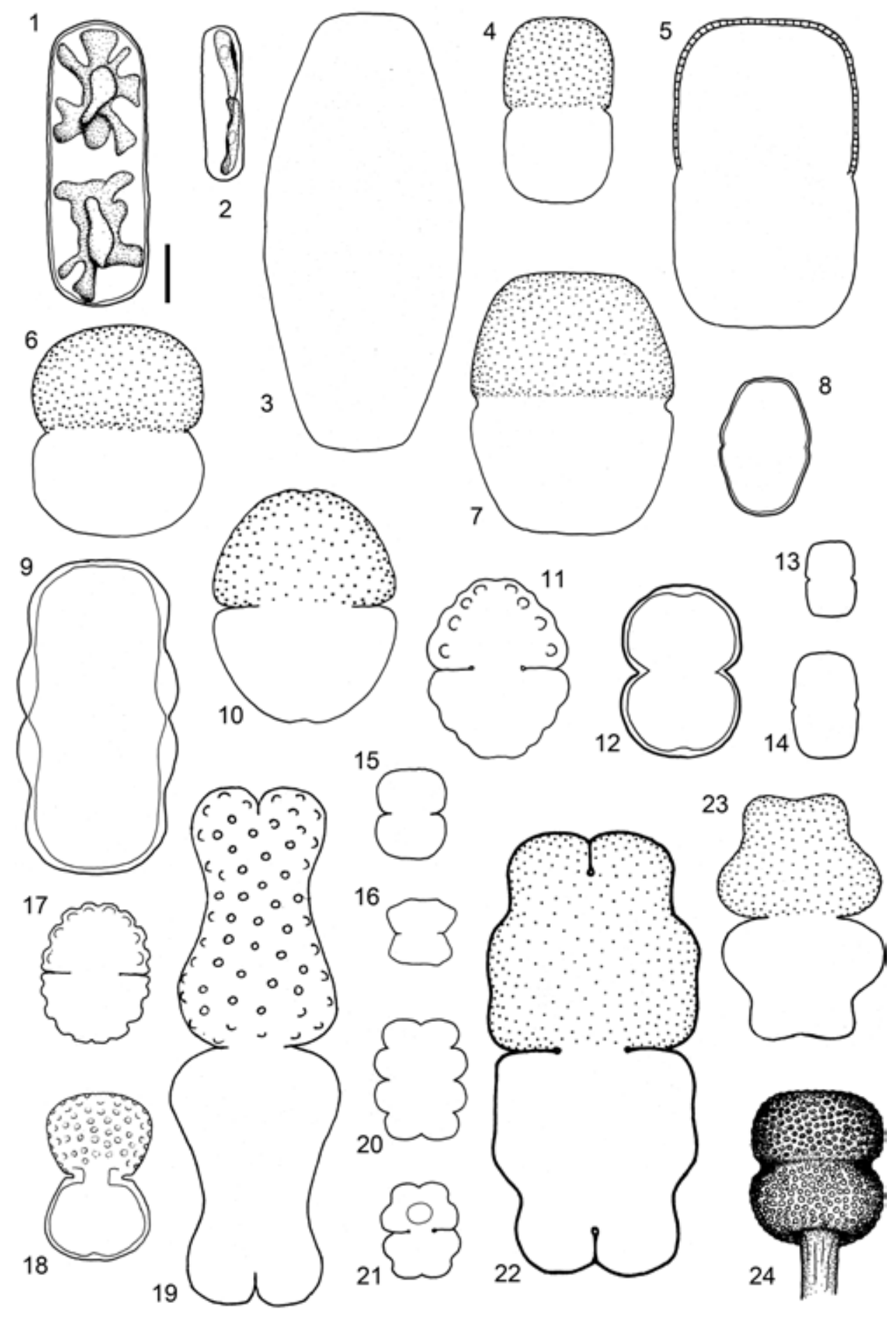


Fig. S2: Desmids II: (1) Micrasterias arcuata - unidentified variety; (2) Micrasterias arcuata var. robusta f. goyazensis; (3) Micrasterias arcuata var. compacta; (4) Micrasterias arcuata var. borgei; (5, 6) Ichthyocercus longispinus; (7) Staurodesmus extensus var. vulgaris; (8) Staurodesmus omearii; (9) Staurastrum cosmarioides; (10) Staurastrum pseudozonatum var. minutissimum; (11) Staurodesmus calyxoides; (12) Staurodesmus cf. wandae - apical view hexaradiate, (13) Staurodesmus cf. wandae - apical view pentaradiate; (14) Staurodesmus cf. wandae; (15) Staurastrum hystrix; (16) Staurastrum elongatum; (17) Staurastrum cf. quadrispinatum; (18) Staurastrum cf. teliferum. Scale bar $10 \mu \mathrm{m}$.

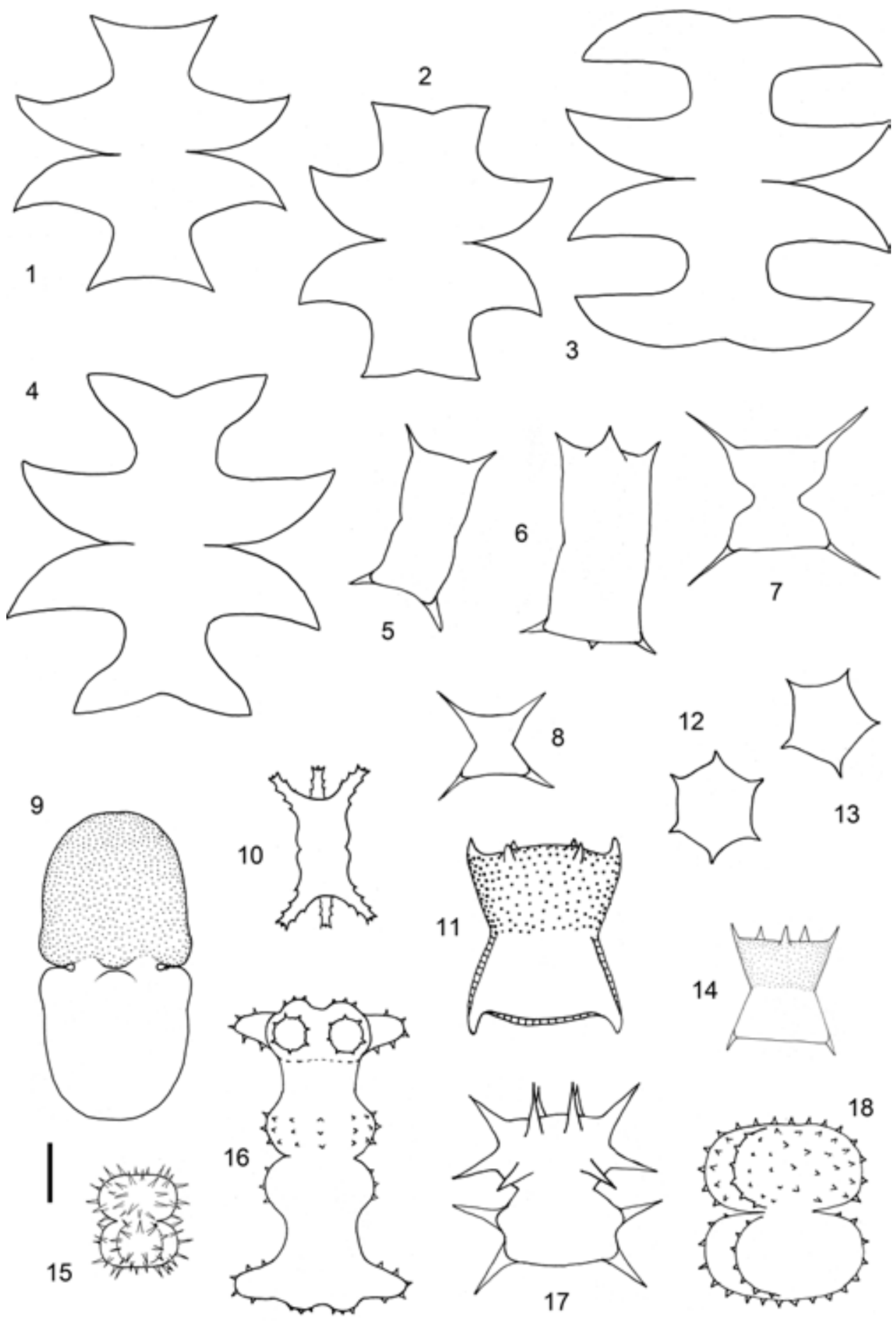


Fig. S3. Diatoms I: (1) Eunotia acutuariola; (2) Eunotia fennica; (3) Eunotia noerpeliana; (4) Eunotia sp. 6; (5) Eunotia cf. geniculata; (6) Eunotia gibbosa; (7) Actinella subperenoides; (8) Peronia sp. 1; (9) Peronia sp. 2; (10) Amphora sp.; (11) Encyonopsis sp. 1; (12) Encyonema sparsipunctatum; (13) Eunotia sp. 7; (14) Eunotia sp. 4; (15) Eunotia sp. 9; (16) Eunotia sp. 8; (17) Eunotia sp. 1. Scale bar $10 \mu \mathrm{m}$.

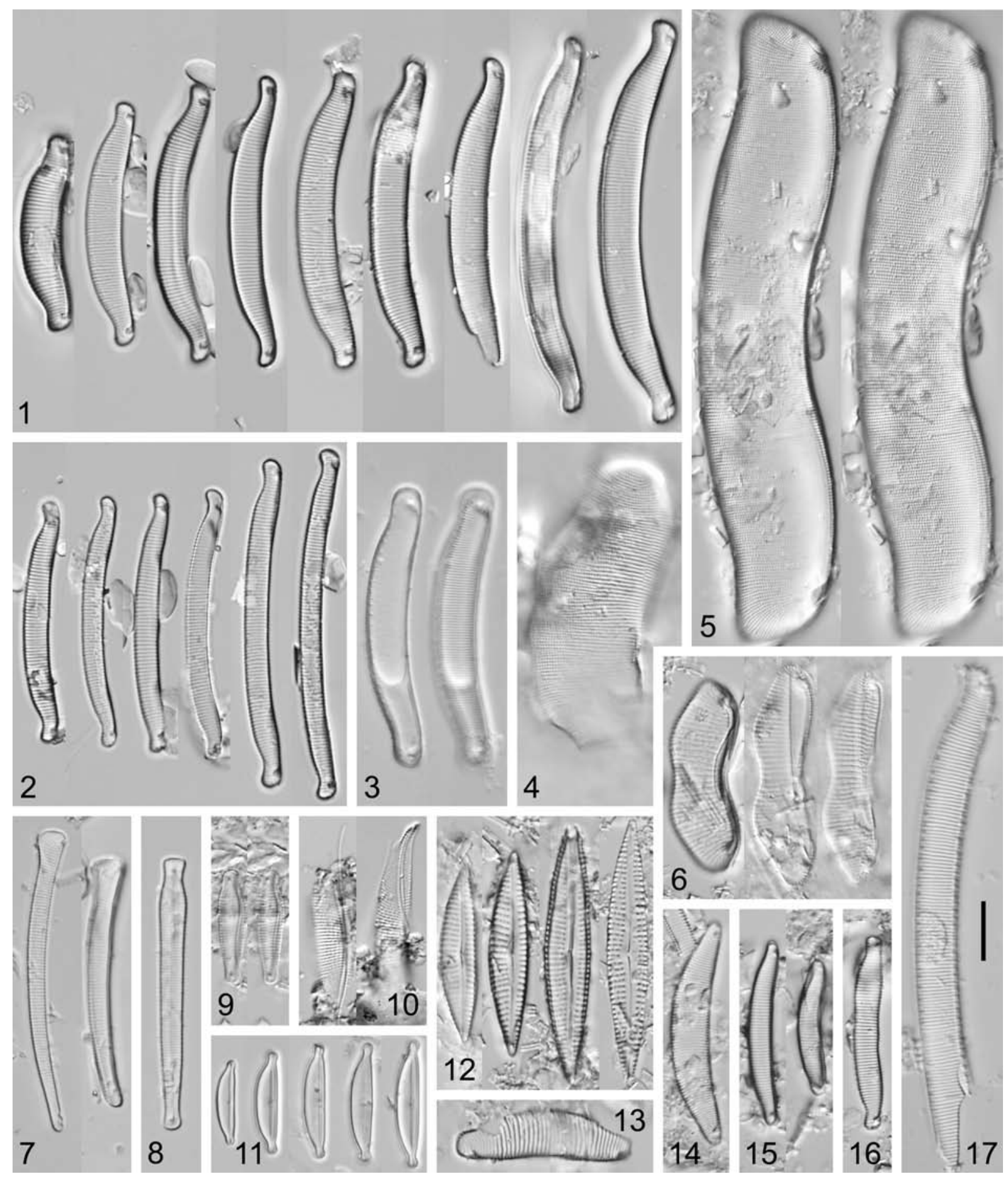


Fig. S4. Diatoms II: (1) Brachysira rostrata; (2) Brachysira serians; (3) Brachysira sp. 1; (4) Luticola muticopsis; (5) Brachysira brebissonii; (6) Luticola sp.; (7) Nitzschia fonticola; (8) Nitzschia amphibia; (9) Frustulia pararhomboides var. pararhomboides; (10) Frustulia undosa; (11) Mastogloia sp.; (12) Kobayasiella pseudosubtilissima; (13) Kobayasiella cf. micropunctata; (14) Hantzschia amphioxys; (15) Fragilarioforma spinulosa; (16) Nitzschia pusilla; (17) Nitzschia hantzschiana; (18) Nitzschia palea; (19) Gomphonema micropus var. micropus; (20) Tryblionella sp. 2; (21) Pinnularia cf. transversiformis. Scale bar 10 $\mu \mathrm{m}$.
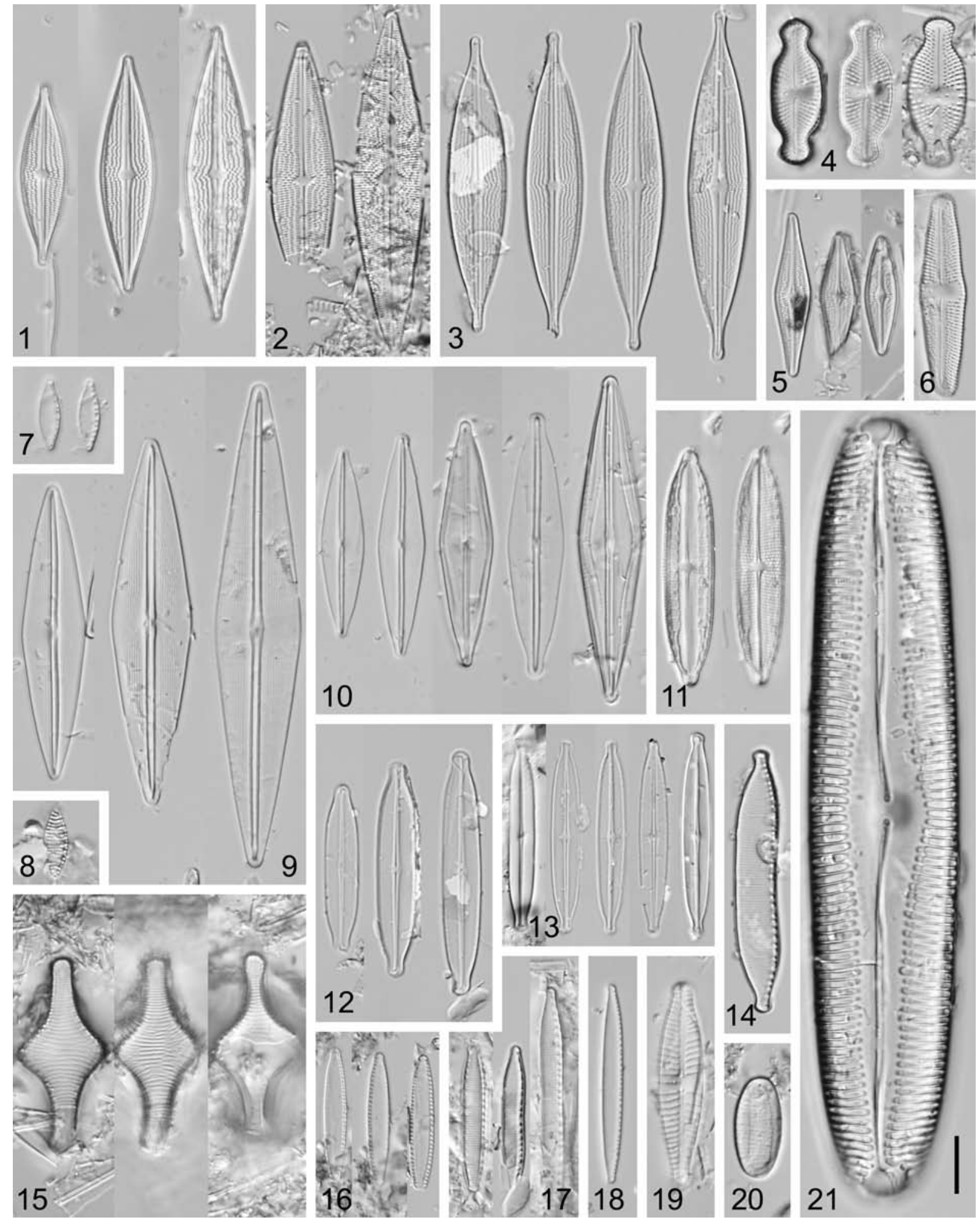